\title{
Mechanistic Insight into the Pyridine Enhanced $\alpha$-Selectivity in Alkyne Hydrothiolation Catalysed by Quinolinolate-Rhodium(I)-N-Heterocyclic Carbene Complexes
}

\author{
Laura Palacios, ${ }^{a}$ Andrea Di Giuseppe, ${ }^{a}$ María José Artigas, ${ }^{a}$ Victor Polo, ${ }^{b}$ Fernando J. Lahoz, ${ }^{a}$ Ricardo \\ Castarlenas, ${ }^{* a}$ Jesús J. Pérez-Torrente, ${ }^{a}$ and Luis A. Oro ${ }^{a, c}$

\begin{abstract}
$\mathrm{Rh}^{\prime}-\mathrm{NHC}$-olefin complexes bearing a $\mathrm{N}, \mathrm{O}$-quinolinolate bidentate ligand have been prepared from $\left[\mathrm{Rh}(\mu-\mathrm{OH})(\mathrm{NHC})\left(\eta^{2} \text {-olefin }\right)\right]_{2}$ precursors (olefin $=$ cyclooctene, ethylene). The disposition of the chelate ligand with regard to the carbene in the square planar derivatives is strongly influenced by the steric hindrance exerted by the coordinated olefin. These complexes efficiently catalyzed the addition of thiophenol to phenylacetylene with good selectivity to $\alpha$-vinyl sulfides, which can be increased up to $97 \%$ by addition of pyridine. Several key intermediates have been detected including the $\eta^{1}$-alkenyl species resulting from alkyne insertion into a Rh-H bond. DFT calculations on the mechanism support a hydrometallation pathway that entails the oxidative addition of thiol, 2,1-insertion of the alkyne into the $\mathrm{Rh}-\mathrm{H}$ bond, and reductive elimination as the rate-determining step. Remarkably, coordination of pyridine to the 6 -alkenyl intermediate but not to the $\alpha$-alkenyl, which results in a net stabilization, is the key for the Markovnikov selectivity.
\end{abstract}

\section{Introduction}

Precise determination of the mechanism of a catalytic process is essential in order to control the selectivity outcome. Particularly, alkyne hydrothiolation is a valuable atomeconomical transformation for the straightforward synthesis of vinyl sulfides, but the control of chemo-, regio- and stereoselectivity still constitutes a stimulating challenge (Scheme 1). ${ }^{1}$ Several methodologies are available for the addition of the $\mathrm{S}-\mathrm{H}$ bond to an unsaturated fragment, including radical initiated, ${ }^{2}$ and acid $^{3}$ or base ${ }^{4}$ promoted, but organometallic catalysts offer mild reaction conditions and the potential for rational design of the catalyst. ${ }^{5}$ Regarding the regioselectivity of the transformation, research efforts have been directed towards the preparation of the more valuable $\alpha$ vinyl sulfides, ${ }^{6}$ which are difficult to synthesize by other methodologies. ${ }^{5 a, d, e, f, h, j, n, r, s}$

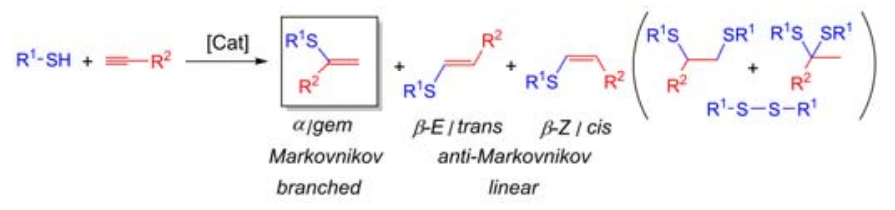

Scheme 1. Alkyne hydrothiolation reaction.

\footnotetext{
a. Departamento de Química Inorgánica-ISQCH, Universidad de Zaragoza-CSIC, C/Pedro Cerbuna 12, CP. 50009, Zaragoza (Spain).e-mail: rcastar@unizar.es. ${ }^{b .}$ Departamento de Química Física, Universidad de Zaragoza, C/Pedro Cerbuna 12, CP. 50009, Zaragoza (Spain).

Center of Research Excellence in Petroleum Refining and Petrochemicals, King Fahd University of Petroleum and Minerals, 31261 Dhahran, (Saudi Arabia). †Electronic Supplementary Information (ESI) available: CIFs of $\mathbf{5 b}, \mathbf{7}$, and $\mathbf{8}$, NMR spectra of complexes, NOESY of $5,6,8$ and $13,{ }^{1} \mathrm{H}^{15} \mathrm{~N} \mathrm{HMBC}$ of 5 and total energies and Cartesian coordinates of theoretical calculations. See DOI: $10.1039 / x 0 x x 00000 x$
}

Pyridine has demonstrated its versatility as additive for a broad spectrum of catalytic reactions. Its contribution to the development of "ligand accelerated catalysis" concept is a prototypical example. ${ }^{7}$ The particular nucleophilic character and its relative small size makes it a suitable ligand for preparation of catalytic precursors as well as for stabilizing organometallic catalytic intermediate species. An enhancement of catalytic activity has been observed for oxidation, ${ }^{8}$ epoxidation, ${ }^{9} \quad \mathrm{C}-\mathrm{H}$ bond functionalization reactions, ${ }^{10}$ as well as alkene oligomerization, ${ }^{11}$ among others. ${ }^{12}$ Noteworthy, pyridine ligands also play an important role in some precatalysts for olefin metathesis ${ }^{13}$ or the $\mathrm{Pd}$ PEPPSI systems. ${ }^{14}$ However, in many cases its role has not been fully understood.

We have recently disclosed new rhodium(I)-N-heterocyclic carbene $(\mathrm{NHC})^{15}$ catalysts for which the selectivity towards the Markovnikov-type adducts is remarkably increased by using pyridine as additive. ${ }^{16}$ It has been observed that dinuclear precursors of type $\left[\mathrm{Rh}(\mu-\mathrm{Cl})(\mathrm{NHC})\left(\eta^{2} \text {-olefin }\right)\right]_{2}$ favour the formation of linear thioethers, whereas the selectivity is switched towards branched gem-vinyl sulfides by the mononuclear catalysts $\mathrm{RhCl}(\mathrm{NHC})$ (pyridine) $\left(\eta^{2}\right.$-olefin), resulting from the bridge-cleavage by the nucleophilic ligand (Scheme 2). In fact, an equilibrium between both type of species is established, rendering the concentration of pyridine essential for the control of regioselectivity. However, catalytic activity was inhibited when the reaction was performed in neat pyridine, indicating that the ligand competes with substrates for coordination to the active species. A ten-fold pyridine/catalyst ratio was chosen in order to get a compromise between activity and selectivity. We now hypothesize that the equilibrium shift to the mononuclear species would increase Markovnikov selectivity. Thus, we envisage anchoring of the pyridine moiety to the catalyst by means of a chelating $\mathrm{N}$-donor ligand. Indeed, a chelate ligand may increase the stability of the catalyst while the structural rigidity of the system would impart a higher steric influence, 
resulting in a better control of selectivity. A promising candidate that fulfils these requirements is the 8-quinolinolate ligand, as it generally forms robust chelate complexes ${ }^{17}$ that have been extensively used in photoluminescent, ${ }^{18}$ biological, ${ }^{19}$ and catalytic ${ }^{20}$ applications.
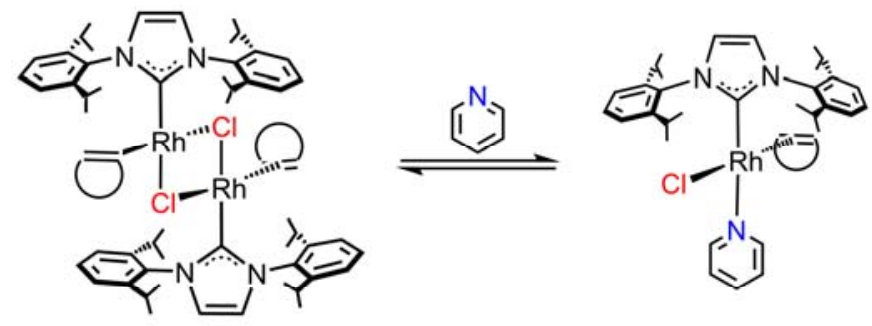

anti-Markovnikov selective

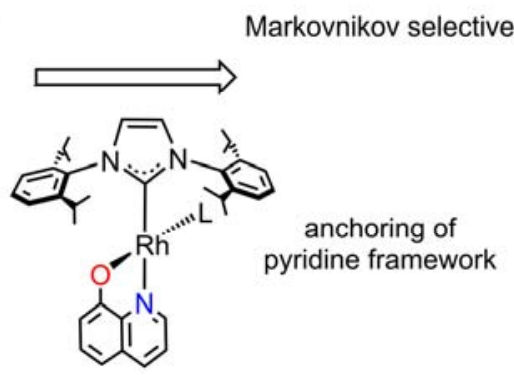

Scheme 2. Strategy for selectivity enhancement by anchorage of the $\mathrm{N}$-donor ligand.

Herein, we report on the preparation of NHC-Rh'quinolinolate derivatives as efficient catalyst for alkyne hydrothiolation. A mechanistic study about the effect of the nitrogenated ligands into the regioselectivity has been undertaken.

\section{Results and Discussion}

\section{Synthesis of Rh-IPr-Quinolinolate Complexes}

Previous studies in our group have shown that dinuclear species $\left[\operatorname{Rh}(\mu-\mathrm{Cl})(\mathrm{IPr})\left(\eta^{2} \text {-olefin }\right)\right]_{2} \quad\{\mathrm{IPr}=1,3-\mathrm{bis}-(2,6-$ diisopropylphenyl)imidazol-2-carbene; olefin = cyclooctene (coe) (1), ethylene (2)\} readily reacts with 8-hydroxyquinoline to form $\mathrm{Rh}^{\text {III }}$ complexes as a result of the oxidative addition of the $\mathrm{O}-\mathrm{H}$ bond. ${ }^{20 \mathrm{~d}, \mathrm{~g}}$ In contrast, the precursors $[\mathrm{Rh}(\mu$ $\mathrm{OH})(\operatorname{IPr})\left(\eta^{2} \text {-olefin) }\right]_{2}$ \{coe (3), ethylene (4)\}, bearing basic hydroxo ligands, have allowed the preparation of $\mathrm{Rh}^{\prime}$ quinolinolate species (Scheme 3). Treatment of a yellow solution of $\mathbf{3}$ with 8-hydroxyquinoline resulted in the instantaneous formation of a tile red solution from which compound $\mathrm{Rh}\left\{\kappa^{2}-\mathrm{O}, \mathrm{N}-\left(\mathrm{C}_{9} \mathrm{H}_{6} \mathrm{NO}\right)\right\}\left(\eta^{2}\right.$-coe $)(\mathrm{IPr})(5)$, was isolated in good yield as a 55:45 thermodynamic mixture of two structural isomers, $\mathbf{5 a}$ and $\mathbf{5 b}$. In contrast, the ethylene precursor 4 gave rise to the formation of $\mathrm{Rh}\left\{\kappa^{2}-\mathrm{O}, \mathrm{N}-\right.$ $\left.\left(\mathrm{C}_{9} \mathrm{H}_{6} \mathrm{NO}\right)\right\}\left(\eta^{2}-\mathrm{CH}_{2}=\mathrm{CH}_{2}\right)(\mathrm{IPr})$ (6) as a single stereoisomer.
Complex 6 can be alternatively prepared by bubbling ethylene through a solution of both isomers of $\mathbf{5}$.

The ${ }^{1} \mathrm{H}$-NMR spectrum of $\mathbf{5}$ shows two set of signals corresponding to each isomer which have different disposition of the $\mathrm{N}, \mathrm{O}$-quinolinolate ligand. The characteristic $\mathrm{H}(2)$ of the quinolinolate ligand appear as doublets at $\delta 8.33 \mathrm{ppm}\left(\mathrm{J}_{\mathrm{H}-\mathrm{H}}=\right.$ $4.9 \mathrm{~Hz})$ for $5 \mathbf{a}$ and $7.84 \mathrm{ppm}\left(\mathrm{J}_{\mathrm{H}-\mathrm{H}}=4.5 \mathrm{~Hz}\right)$ for $\mathbf{5 b}$, whereas the olefinic protons of coordinated coe resonate at 3.04 (5a) and $3.44 \mathrm{ppm}(\mathbf{5 b})$. The more significant resonances in the ${ }^{13} \mathrm{C}\left\{{ }^{1} \mathrm{H}\right\}-$ APT NMR spectrum are two set of doublets at $\delta 184.7\left(J_{\mathrm{C}-\mathrm{Rh}}=\right.$ $\left.59.2 \mathrm{~Hz}, \mathrm{Rh}-\mathrm{C}_{\mathrm{IPr}}\right)$ and $55.3 \mathrm{ppm}\left(J_{\mathrm{C}-\mathrm{Rh}}=15.4 \mathrm{~Hz}, \mathrm{Rh}-\mathrm{C}_{\mathrm{coe}}\right)$ for $\mathbf{5 a}$ and $193.0\left(J_{\mathrm{C}-\mathrm{Rh}}=56.2 \mathrm{~Hz}, \mathrm{Rh}-\mathrm{C}_{\mathrm{IPr}}\right)$ and $65.9 \mathrm{ppm}\left(J_{\mathrm{C}-\mathrm{Rh}}=15.0\right.$ $\mathrm{Hz}, \mathrm{Rh}-\mathrm{C}_{\text {coe }}$ ) for $\mathbf{5 b}$. The ${ }^{1} \mathrm{H}-\mathrm{NMR}$ spectrum of $\mathbf{6}$ shows a single resonance for the $\mathrm{H}(2)$ proton at $\delta 6.77 \mathrm{ppm}\left(\mathrm{dd}, J_{\mathrm{H}-\mathrm{H}}=4.9,1.0\right.$ $\mathrm{Hz}$ ), while the ${ }^{13} \mathrm{C}\left\{{ }^{1} \mathrm{H}\right\}$-APT NMR spectrum displays two doublets at $186.8 \mathrm{ppm}\left(J_{\mathrm{C}-\mathrm{Rh}}=56.7 \mathrm{~Hz}\right)$ and $36.6 \mathrm{ppm}\left(J_{\mathrm{C}-\mathrm{Rh}}=\right.$ $16.2 \mathrm{~Hz}$ ) for the carbene and ethylene ligands, respectively, which is in agreement with the presence of a single isomer. In addition, a rotational process for the $\mathrm{IPr}$ and ethylene ligands is observed. $^{21}$

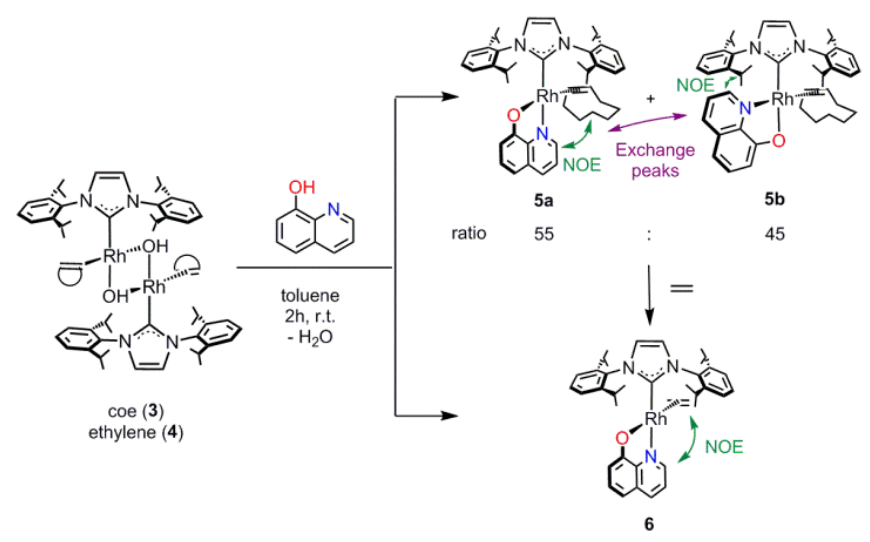

Scheme 3. Synthesis of $\mathrm{Rh}^{\prime}$-quinolinolate complexes 5-6.

The ${ }^{1} \mathrm{H}$ 1D-NOESY experiments confirms the structural assignment for $\mathbf{5 a}, \mathbf{5 b}$ and $\mathbf{6}$ in Scheme 3 (see SI). Irradiation of the major $\mathrm{H}(2)$ quinolinolate signal at $\delta 8.33 \mathrm{ppm}$ showed NOE effect with coe ligand, indicating that the nitrogen atom is disposed trans to IPr in 5a. Similarly, the interaction between the minor $\mathrm{H}(2)$ resonance at $\delta 7.84 \mathrm{ppm}$ with the substituents of the carbene confirms a mutually cis disposition in $\mathbf{5 b}$. In addition, exchange peaks between quinolinolate resonances of both isomers were observed indicating a dynamic equilibrium. On the other hand, irradiation of the ethylene resonance of 6 caused NOE effect on $\mathrm{H}(2)$ quinolinolate proton pointing to trans disposition of the nitrogen atom and the IPr ligand. The ${ }^{1} \mathrm{H}-{ }^{15} \mathrm{~N}$ HMBC spectra also support the above structural assignment. Two signals are observed for the $\mathrm{N}$-donor ligand at $\delta 252.8$ (5a) and 248.3 ppm (5b), comparative more shielded than the free ligand (288.0 ppm), as a result of coordination to the rhodium atom (see $\mathrm{SI}) .{ }^{22}$ The quinolinolate nitrogen atom of 6 resonates at $253.3 \mathrm{ppm}$ which is in accordance with a stereochemistry similar to $\mathbf{5 a}$. 
The solid state structure for $\mathbf{5 b}$ was determined by an X-ray diffraction analysis (Figure 1). The rhodium atom presents a distorted square-planar geometry with the nitrogen atom of the quinolinolate ligand located cis to the $\operatorname{IPr}\{\mathrm{C}(1)-\mathrm{Rh}-\mathrm{N}(1)=$ $\left.94.51(14)^{\circ}\right\}$. The rhodium-carbon separation $\{\mathrm{Rh}-\mathrm{C}(1)=$ 1.943(4) $\AA$ \} lays in the range of short distances previously reported for a Rh-NHC single bond. In contrast, the Rh-N(1) $\{2.137(3) \AA\}$ and $\mathrm{Rh}-\mathrm{O}(1)\{2.104(3) \AA$ A $\}$ bonds are rather long. The olefinic separation of 1.390(6) $\AA$ agrees with that reported for other Rh-coe-NHC complexes. ${ }^{16 b, 21,23}$ The quinolinic and imidazole rings are almost planar and disposed perpendicularly each other forming a dihedral angle of $89.88(11)^{\circ}$.

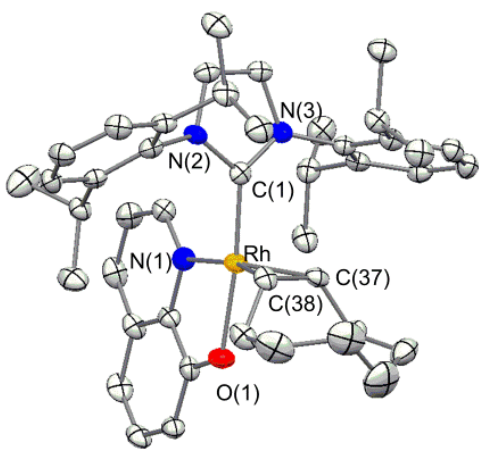

Figure 1. Molecular structure of $\mathbf{5 b}$. Selected bond lengths $(\AA)$ and angles $\left({ }^{\circ}\right)$ : Rh-C $(1)=1.943(4), \operatorname{Rh}-\mathrm{N}(1)=2.137(3), \mathrm{Rh}-\mathrm{O}(1)=2.104(3)$, $\mathrm{Rh}-\mathrm{C}(37)=2.109(4), \mathrm{Rh}-\mathrm{C}(38)=2.108(4), C(37)-C(38)=1.390(6)$, $\mathrm{C}(1)-\mathrm{Rh}-\mathrm{N}(1)=94.51(14), \mathrm{C}(1)-\mathrm{Rh}-\mathrm{O}(1)=172.91(13), \mathrm{C}(1)-\mathrm{Rh}^{-\mathrm{Ct}}{ }^{*}=$ 92.50(14), N(1)-Rh-O(1) = 78.88(11), N(1)-Rh-Ct* ${ }^{*}$ 171.18(12) $\left(\mathrm{Ct}^{*}\right.$ represents the midpoint of the olefinic bond).

The existence of two isomers for $\mathbf{5}$ is a rather unexpected result. Recent calculations in our group for a series of Rh-IPr complexes $^{23 d}$ have revealed that a $\mathrm{N}$-donor ligand such as pyridine shows an electronic preference to coordinate opposite to the high trans-influence ligand IPr. Indeed, a trans disposition between the more $\pi$-acceptor ligand, the olefin, and the more electron-donating oxygen atom of the quinolinolate ligand should be also favoured, as it has been observed in related complexes. ${ }^{23 a, 24}$ Thus, the formation of the unexpected isomer $\mathbf{5 b}$ for the coe derivative could be a consequence of the interplay between steric and electronic factors. In order to shed light into the influence of the coordinated olefin into the disposition of the quinolinolate ligand, the synthesis of rhodium complexes with the bulkier 2methyl-8-quinolinolate ligand was undertaken (Scheme 4). Treatment of $\mathbf{3}$ with 2-methyl-8-hydroxyquinoline in toluene$d_{8}$ at $-40{ }^{\circ} \mathrm{C}$ resulted in the formation of $\mathrm{Rh}\left\{\kappa^{2}-\mathrm{O}, \mathrm{N}-\right.$ $\left.\left[\left(\mathrm{C}_{9} \mathrm{H}_{5} \mathrm{NO}\right)\left(\mathrm{CH}_{3}\right)\right]\right\}\left(\eta^{2}\right.$-coe)(IPr) (7). Unfortunately, 7 decomposes at room temperature and could not be isolated, but it was fully characterized at low temperature by NMR, showing the presence of a single stereoisomer. Similarly, the ethylene precursor 4 gave a single isomer of the complex $\operatorname{Rh}\left\{\kappa^{2}-\mathrm{O}, \mathrm{N}-\right.$
$\left.\left[\left(\mathrm{C}_{9} \mathrm{H}_{5} \mathrm{NO}\right)\left(\mathrm{CH}_{3}\right)\right]\right\}\left(\eta^{2}-\mathrm{CH}_{2}=\mathrm{CH}_{2}\right)(\mathrm{IPr})(8)$ that was isolated as an orange solid in $65 \%$ yield.

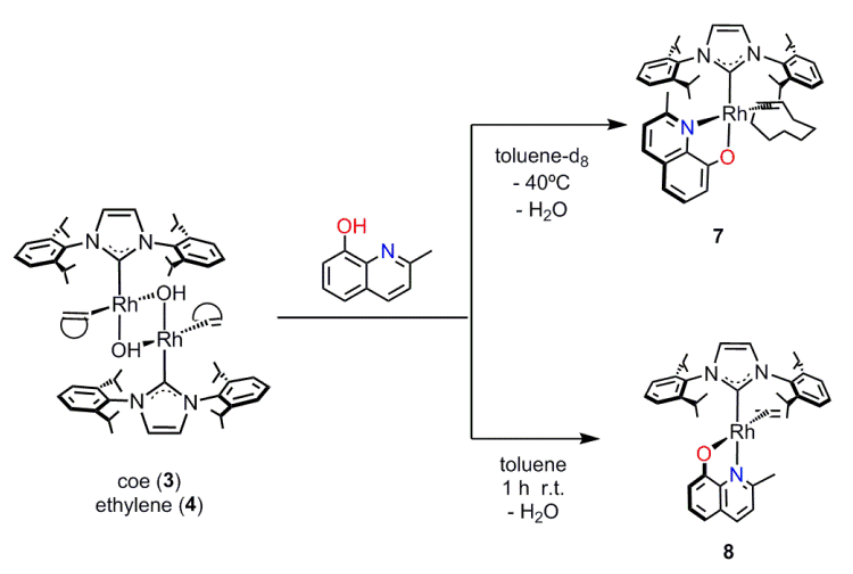

Scheme 4. Synthesis of 2-methyl-8-quinolinolate complexes 7 and 8.

The molecular structure of compounds $\mathbf{7}$ and $\mathbf{8}$ has been determined by X-ray diffraction analysis (Figure 2). Both complexes adopt a distorted square planar configuration with the nitrogen atom of the 2-methyl-8-quinolinolate ligand coordinated trans to the coe ligand in $7\{\mathrm{C}(1)-\mathrm{Rh}-\mathrm{N}(3)=$ $\left.101.03(7)^{\circ}\right\}$, as in the isomer $\mathbf{5 b}$, but trans to IPr ligand in 8 $\left\{\mathrm{C}(1)-\mathrm{Rh}-\mathrm{N}(3)=169.83(6)^{\circ}\right\}$, similarly to complex 6 . The Rh- $\mathrm{C}_{\mathrm{IPr}}$ distances are comparative short with regard to previous $\mathrm{Rh}$ NHC complexes $\{\mathbf{7}, 1.9495(18) ; 8,1.9666(15) \AA ̊$.$\} . The presence$ of a methyl substituent causes a lengthening of the Rh- $\mathrm{N}$ bond from 2.137(3) $\AA$ in 5b to 2.2809(16) $\AA$ in 7, and a slight shortening of the Rh-O bond $\{2.0785(14)$ in 7 vs $2.104(3)$ in $5 b$. In addition, the N-Rh-IPr angle increase from $94.51(14)^{\circ}$ (5b) to $101.03(7)^{\circ}(7)$ showing once again the steric influence.
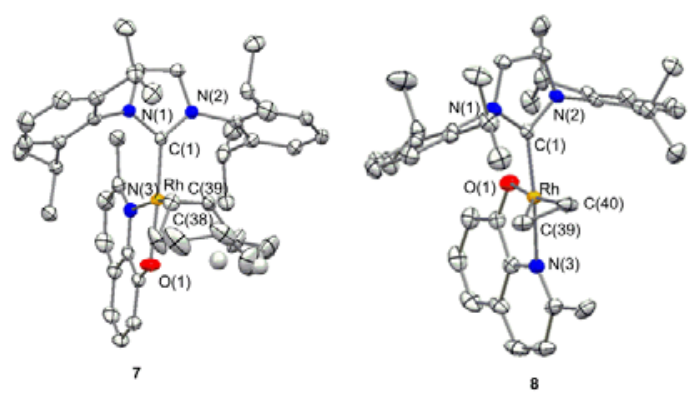

Figure 2. Molecular structures of $\mathbf{7}$ and $\mathbf{8}$. Selected bond lengths (Å) and angles $\left({ }^{\circ}\right)$. 7: $\mathrm{Rh}-\mathrm{C}(1)=1.9495(18), \mathrm{Rh}-\mathrm{N}(3)=2.2809(16)$, Rh$\mathrm{O}(1)=2.0785(14), \mathrm{Rh}-\mathrm{C}(38)=2.0996(19), \mathrm{Rh}-\mathrm{C}(39)=2.0905(19)$, $\mathrm{C}(38)-\mathrm{C}(39)=1.396(3), \mathrm{C}(1)-\mathrm{Rh}-\mathrm{N}(3)=101.03(7), \mathrm{C}(1)-\mathrm{Rh}-\mathrm{O}(1)=$ 176.75(7), N(3)-Rh-O(1) = 77.58(6), C(1)-Rh-Ct* = 90.04(8). 8: Rh$\mathrm{C}(1)=1.9666(15), \mathrm{Rh}-\mathrm{N}(3)=2.1809(13), \mathrm{Rh}-\mathrm{O}(1)=2.0478(11)$, Rh$C(39)=2.0772(17), R-C(40)=2.1293(18), C(39)-C(40)=1.392(3)$, $\mathrm{C}(1)-\mathrm{Rh}-\mathrm{N}(3)=169.83(6), \mathrm{C}(1)-\mathrm{Rh}-\mathrm{O}(1)=90.33(5), \mathrm{N}(3)-\mathrm{Rh}-\mathrm{O}(1)=$ 79.51(5), $\mathrm{C}(1)-\mathrm{Rh}^{-\mathrm{Ct}^{*}}=90.28(4)(\mathrm{Ct} *$ represents the midpoint of the olefinic bond). 
The solid state structures of $\mathbf{7}$ and $\mathbf{8}$ are maintained in solution as inferred from ${ }^{1} \mathrm{H}$ and ${ }^{13} \mathrm{C}\left\{{ }^{1} \mathrm{H}\right\}$ NMR data. The methyl substituent of the quinolinolate ligand exerts a significant steric effect that influences the intrinsic dynamic behaviour of the complexes. Thus, in contrast to $\mathbf{5 b}$, the rotation of the IPr ligand is hindered in complex $7 .^{25}$ In the same way, ethylene rotation is hampered in $\mathbf{8}$ which contrast to the free rotation observed at room temperature in $\mathbf{6}^{26}$

Theoretical DFT calculations on the ground state energies of complexes 5-8 were performed in order to corroborate the preferential disposition of the quinolinolate ligand in $\mathrm{Rh}^{\mathrm{I}}-\pi$ olefin complexes (Figure 3 ). In accordance with the experimental observations, the configuration with the nitrogen atom of the quinolinolate ligand trans to the carbene is more stable for 5, 6 and 8, whereas the opposite configuration is the minimum for 7 . The energy separation of only $0.6 \mathrm{kcal} \mathrm{mol}^{-1}$ for 5 agrees with the observation of both isomers. The unexpected disposition of the quinolinolate ligand found in complexes $\mathbf{5}$ and $\mathbf{7}$ is a consequence of the steric influence imparted by the coe ligand. Careful observation of the putative complex 7at evidences a harsh steric hindrance between the methyl group and coe if compared with that exerted by the IPr in $\mathbf{7 b t}$ (Figure 4). The fact that the steric influence of coe in these complexes is greater than that of the carbene could be in principle paradoxical due to the bulkiness of the IPr ligand. ${ }^{15}$ However, the anisotropy of IPr allows the methyl group of the quinolinolate to accommodate between the bisisopropylphenyl wingtips of the carbene. ${ }^{27}$ In contrast, the pseudo-spherical cyclooctene ligand do not allow for this steric relief, thus exerting higher steric hindrance.
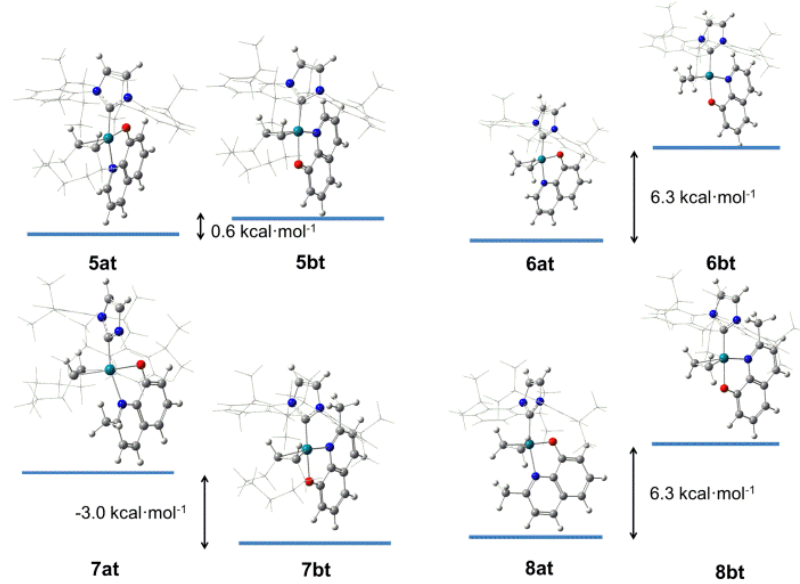

Figure 3. DFT-optimized ground state minimum energy structures for complexes 5-8.

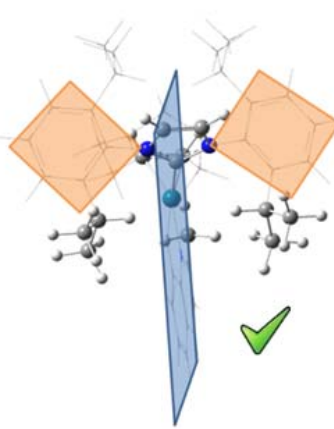

$7 b t$

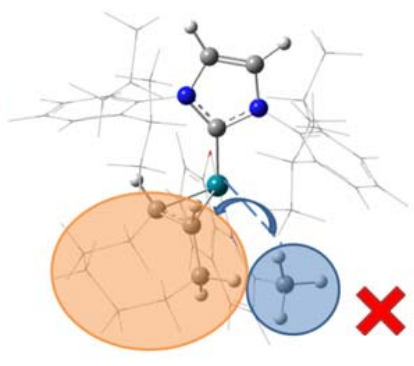

7at
Figure 4. Comparison of the steric hindrance exerted by coe and IPr ligands on the 2-methyl-quinolinolate ligand in $\mathbf{7}$.

\section{Catalytic Activity in Alkyne Hydrothiolation}

Catalytic activity of complexes 5, 6 and 8 for alkyne hydrothiolation was evaluated. The addition of thiophenol to phenylacetylene using a 1:1 ratio was chosen as benchmark reaction. Catalytic reactions were monitored in NMR tubes containing $0.5 \mathrm{~mL}$ of $\mathrm{C}_{6} \mathrm{D}_{6}$ and $2 \mathrm{~mol} \%$ of catalyst loading at 25 ${ }^{\circ} \mathrm{C}$ (Table 1, Figure 5).

The introduction of the quinolinolate ligand into the RhNHC framework significantly affects the catalytic outcome compared to related catalytic systems previously described by us (entries 1-4 vs 5-10). ${ }^{16}$ In general, the catalytic activity is lower, as observed in the aforementioned systems by the addition of pyridine (entries 2-4 vs 1-3). As we hypothesized, the selectivity to $\alpha$-vinyl sulfides of the quinolinolate-based catalysts is high (74-80\%), but, unfortunately, lower than expected (entries 5, 7 and 9). Remarkably, the addition of pyridine results in an increase of the selectivity up to $97 \%$ (entries 6, 8 and 10) with an upsurge of the catalytic activity except for catalyst precursor $\mathbf{8}$. The use of $\mathrm{NEt}_{3}$ as additive gave poorer results suggesting that the role played by pyridine is the coordination to the metallic centre and not as a base (entry 11). However, it seems that coordinating ability of the additive is essential for an efficient catalytic system, as reflected in the lower activity observed when much weaker coordinating ligands such as $\mathrm{CH}_{3} \mathrm{CN}$ or 2-ethylpyridine were used (entries 12 and 13). 
Table 1. Phenylacetylene hydrothiolation with thiophenol promoted by Rh-IPr catalysts. $^{a}$

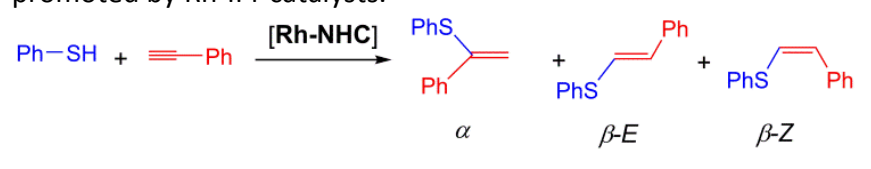

\begin{tabular}{|c|c|c|c|c|c|c|}
\hline Entry & Cat & Additive $^{b}$ & $t(h)$ & Conv $\%^{c}$ & $\alpha / \beta-E$ & $\mathrm{TOF}_{1 / 2}{ }^{d}$ \\
\hline $1^{e}$ & 2 & - & 0.4 & 99 & $33 / 67$ & 482 \\
\hline $2^{e}$ & 2 & & 7 & 99 & $94 / 6$ & 22 \\
\hline $3^{f}$ & 4 & - & 14 & 99 & $82 / 18$ & 41 \\
\hline $4^{f}$ & 4 & & 14 & 91 & $94 / 6$ & 28 \\
\hline 5 & $\mathbf{5}^{g}$ & 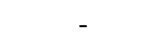 & 14 & 58 & $74 / 26$ & 3 \\
\hline 6 & $5^{g}$ & & 16 & 79 & $97 / 3$ & 11 \\
\hline 7 & 6 & - & 16 & 40 & $80 / 20$ & $1.3^{h}$ \\
\hline 8 & 6 & & 15 & 70 & $93 / 7$ & 4 \\
\hline 9 & 8 & - & 13 & 90 & $79 / 21$ & 15 \\
\hline 10 & 8 & & 15 & 80 & $97 / 3$ & 5 \\
\hline 11 & $5^{g}$ & $\mathrm{NEt}_{3}$ & 19 & 31 & $63 / 37$ & - \\
\hline 12 & $\mathbf{5}^{g}$ & $\mathrm{CH}_{3} \mathrm{CN}$ & 20 & 35 & $61 / 36 / 3^{i}$ & - \\
\hline 13 & $5^{g}$ & & 20 & 30 & $65 / 35$ & - \\
\hline
\end{tabular}

${ }^{a} 0.5 \mathrm{~mL}$ of $\mathrm{C}_{6} \mathrm{D}_{6}$ with $2 \mathrm{~mol} \%$ of catalyst, [alkyne] = [thiol] = $1.0 \mathrm{M}$ at $25^{\circ} \mathrm{C} .{ }^{b} 10$ equivalents. ${ }^{c}$ Relative to phenylacetylene. ${ }^{d}$ Turnover Frequency in $\mathrm{h}^{-1}$ at $50 \%$ conversion. ${ }^{e}$ Data from ref 16a. ${ }^{f}$ Data from ref $16 \mathrm{~b} .{ }^{g}$ Mixture of 5a and $\mathbf{5 b} .{ }^{h}$ Determined at $25 \%$ of conversion. ${ }^{i} B-Z$ vinyl sulfide.

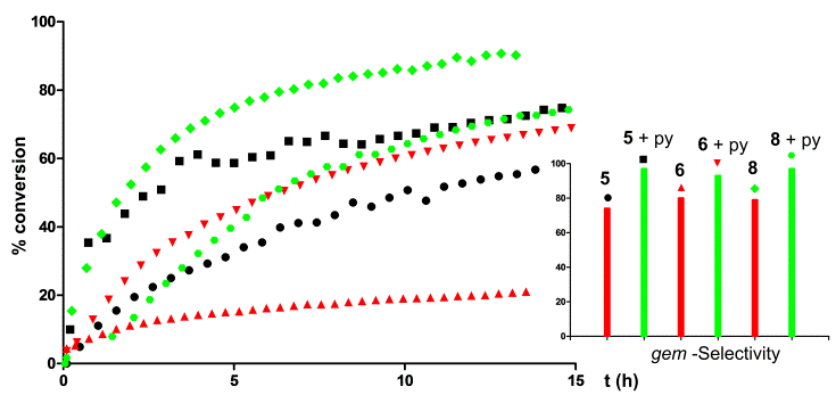

Figure 5. Monitorization of phenylacetylene hydrothiolation catalysed by 5, 6, 8 in the presence or absence of pyridine.

\section{Mechanistic Studies for Alkyne Hydrothiolation}

The above described results evidence that both $\mathrm{N}$-donor ligands play a key role on the performance of the catalytic system. We assume that, similarly to related catalytic systems based on Rh-NHC catalyst precursors described by us, the first step in the catalytic reaction should be the oxidative addition of the thiol to form a $\mathrm{Rh}^{\text {III }}$ species stabilized by the coordination of pyridine (Figure 6). ${ }^{16 a}$ In previous works, we have observed related octahedral intermediates bearing two pyridine ligands located trans and cis to the carbene, which probably exert different influence on the mechanism, but could not be analysed independently. The presence of a quinolinolate ligand makes possible to study the effect of the coordinated ligands in both positions. In one hand, the bidentate coordination of the quinolinolate ligand inhibits the equilibrium with dinuclear species thereby increasing the selectivity to Markovnikov-type products. However, the positive effect of pyridine in the regioselectivity suggests that its coordination cis to the carbene ligand is also significant.

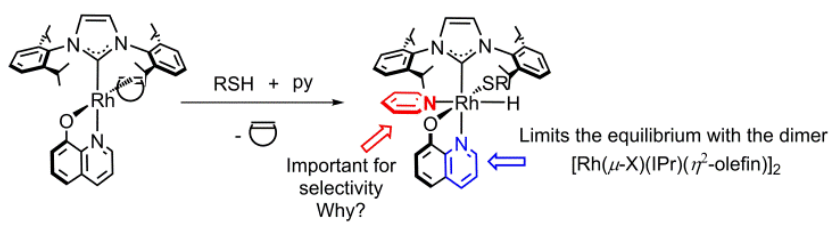

Figure 6. Role of the $\mathrm{N}$-donor ligands in the active species.

A series of stoichiometric reactions were carried out in order to gain insight into the reaction mechanism. Addition of thiophenol to a NMR tube containing a toluene- $d_{8}$ solution of 5 afforded, after $1 \mathrm{~h}$ at room temperature, the Rh-hydride unsaturated complex $\mathrm{RhH}\left\{\kappa^{2}-\mathrm{O}, \mathrm{N}-\left(\mathrm{C}_{9} \mathrm{H}_{6} \mathrm{NO}\right)\right\}(\mathrm{SPh})(\mathrm{IPr})(9)$ as a result of the $\mathrm{S}-\mathrm{H}$ oxidative addition (Scheme 5$).{ }^{28}$ The hydride ligand of 9 was observed in the ${ }^{1} \mathrm{H}$ NMR spectrum as a doublet at $\delta-26.74 \mathrm{ppm}$ with $J_{\mathrm{H}-\mathrm{H}}=51.4 \mathrm{~Hz}$ (Figure 7). The large coupling constant points to a square pyramidal structure with the hydride ligand in the apical position. ${ }^{20 \mathrm{e}}$ Addition of pyridine to a solution of in situ prepared $\mathbf{9}$ in a NMR tube led to the formation of the saturated complex $\mathrm{RhH}\left\{\kappa^{2}-\mathrm{O}, \mathrm{N}\right.$ $\left.\left(\mathrm{C}_{9} \mathrm{H}_{6} \mathrm{NO}\right)\right\}(\mathrm{SPh})(\mathrm{IPr})(\mathrm{py})(\mathbf{1 0})$. The hydride resonance of $\mathbf{1 0}$ is shifted to $-16.02 \mathrm{ppm}$ and the $\mathrm{Rh}-\mathrm{H}$ coupling constant is substantially reduced to $19.7 \mathrm{~Hz}$, in accordance with the proposed octahedral structure. ${ }^{29}$ Compounds $\mathbf{9}$ and $\mathbf{1 0}$ are in a dynamic equilibrium with a 9:10 ratio of 5:95 at $-60{ }^{\circ} \mathrm{C}$. It is worthy to note that, in spite of starting from a mixture of $\mathrm{Rh}^{\prime}$ complexes with different orientation of the quinolinolate ligand, only a single isomer was observed for $\mathbf{9}$ and $\mathbf{1 0}$. Several attempts for isolation of $\mathbf{9}$ and $\mathbf{1 0}$ were unsuccessful. DFT calculations show that the configuration of $\mathbf{9}$ with the nitrogen atom of quinolinolate ligand trans to IPr is $10.8 \mathrm{kcal} \mathrm{mol}^{-1}$ more stable than the opposite orientation, as observed previously in related $\mathrm{Rh}^{\text {III }}$-quinolinolate complexes. ${ }^{20 \mathrm{~d}, \mathrm{~g}}$ 


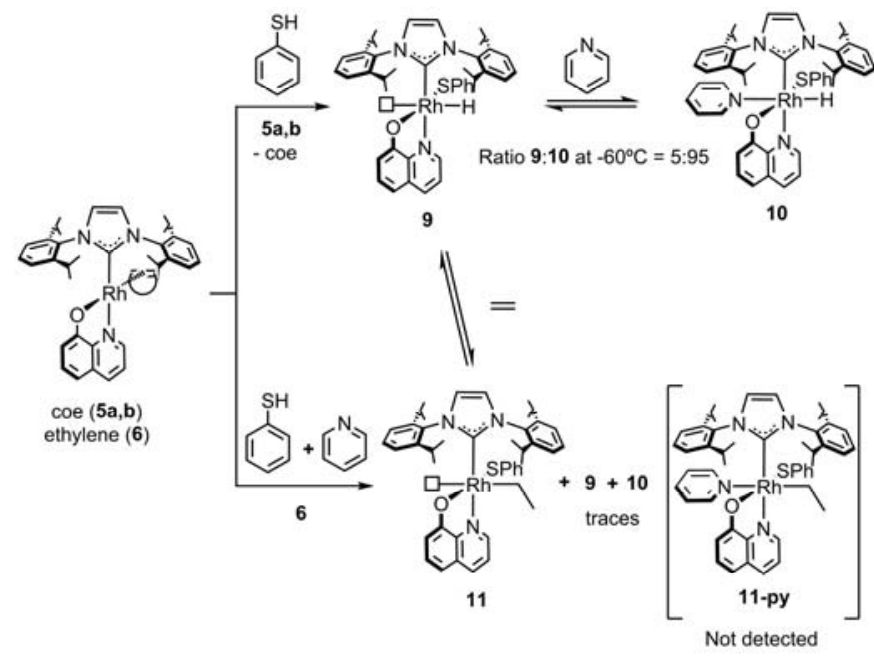

Scheme 5. Sequential reaction of $\mathbf{5}$ and $\mathbf{6}$ with thiophenol and pyridine.

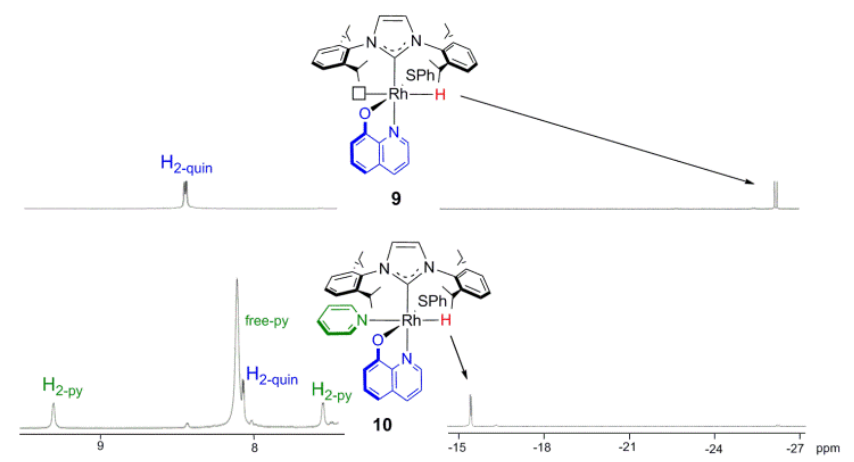

Figure 7. Aromatic and hydride regions of the ${ }^{1} \mathrm{H}-\mathrm{NMR}$ spectra of 9 and 10 at $-60{ }^{\circ} \mathrm{C}$.

The outcome of the reaction of the ethylene compound 6 with thiophenol is somewhat different. Treatment of 6 with the thiol and pyridine in an NMR tube afforded the unsaturated Rh-ethyl complex $\mathrm{Rh}\left(\eta^{1}-\mathrm{CH}_{2} \mathrm{CH}_{3}\right)\left\{\kappa^{2}-\mathrm{O}, \mathrm{N}-\right.$ $\left.\left(\mathrm{C}_{9} \mathrm{H}_{6} \mathrm{NO}\right)\right\}(\mathrm{SPh})(\mathrm{IPr})$ (11), as a result of $\mathrm{S}-\mathrm{H}$ oxidative addition and subsequent insertion of ethylene into the newly formed $\mathrm{Rh}-\mathrm{H}$ bond, ${ }^{30}$ whereas, in contrast to 9 , the formation of the octahedral pyridine complex was not observed. Traces of $\mathbf{9}$ and 10 were detected. The ${ }^{1} \mathrm{H}$ NMR spectrum shows a set of three multiplets for the ethyl ligand at $\delta 3.20,2.92$, and $-0.36 \mathrm{ppm}$ corresponding to the diastereotopic $>\mathrm{CH}_{2}$ and $-\mathrm{CH}_{3}$ protons, respectively. In addition, two doublets at $\delta 20.4\left(J_{\mathrm{Rh}-\mathrm{C}}=27.1\right.$ $\mathrm{Hz})$ and $174.0 \mathrm{ppm}\left(J_{\mathrm{Rh}-\mathrm{C}}=53.2 \mathrm{~Hz}\right)$ appear in the ${ }^{13} \mathrm{C}\left\{{ }^{1} \mathrm{H}\right\}-\mathrm{APT}$ spectrum, ascribed respectively to ethyl and IPr carbon atoms attached to rhodium. Complex $\mathbf{1 1}$ has also been detected when bubbling ethylene through a solution of $\mathbf{9}$.

In the next step, we have studied the insertion reaction of the alkyne into hydride-thiolate-Rh"I species. Treatment of a freshly insitu prepared solution of $\mathbf{9}$ with phenylacetylene led, after $1 \mathrm{~h}$ at room temperature, to the formation of the alkenyl derivatives $\mathrm{Rh}\left(\eta^{1}-\mathrm{C}(\mathrm{Ph})=\mathrm{CH}_{2}\right)\left\{\kappa^{2}-\mathrm{O}, \mathrm{N}-\left(\mathrm{C}_{9} \mathrm{H}_{6} \mathrm{NO}\right)\right\}(\mathrm{SPh})(\mathrm{IPr}) \quad(12)$ and $\mathrm{Rh}\left(\eta^{1}-\right.$
$\mathrm{CH}=\mathrm{CHPh})\left\{\kappa^{2}-\mathrm{O}, \mathrm{N}-\left(\mathrm{C}_{9} \mathrm{H}_{6} \mathrm{NO}\right)\right\}(\mathrm{SPh})(\mathrm{IPr})(13)$ in a 56:44 ratio, as a result of the alkyne insertion into the $\mathrm{Rh}-\mathrm{H}$ bond with Markovnikov or anti-Markovnikov regioselectivity, respectively (Scheme 6). ${ }^{31}$ Alkyne insertion into the Rh-S bond was not detected. ${ }^{32}$ The ${ }^{1} \mathrm{H}$ NMR spectrum shows the characteristic $H(2)$ resonances for the quinolinolate ligand at $\delta 8.86$ (12) and $8.64 \mathrm{ppm}(\mathbf{1 3})$, whereas two doublets are observed in the ${ }^{13} \mathrm{C}\left\{{ }^{1} \mathrm{H}\right\}$-APT spectrum at $174.5\left(J_{\mathrm{Rh}-\mathrm{C}}=\right.$ $54.3 \mathrm{~Hz})(12)$ and $172.3 \mathrm{ppm}\left(J_{\mathrm{Rh}-\mathrm{C}}=51.5 \mathrm{~Hz}\right)(13)$ corresponding to the Rh-IPr carbon atoms, corroborating the presence of two new complexes. Methylidene protons of 12 resonate at $\delta 4.77$ and 4.73 ppm as broad signals and correlate in the ${ }^{1} \mathrm{H}_{-}{ }^{13} \mathrm{C} \mathrm{HSQC}$ spectrum with the same $=\mathrm{CH}_{2}$ carbon atom at $123.6 \mathrm{ppm}$. Confirmation of the $\eta^{1}$ - $\alpha$-alkenyl moiety in $\mathbf{1 2}$ arises from the correlation in the ${ }^{1} \mathrm{H}-{ }^{13} \mathrm{C}$ $\mathrm{HMBC}$ spectrum between the $=\mathrm{CH}_{2}$ protons and a quaternary carbon at $\delta 143.4 \mathrm{ppm}$, appearing as a doublet $\left(J_{\mathrm{Rh}-\mathrm{C}}=37.8 \mathrm{~Hz}\right)$, corresponding to the vinylic carbon attached to rhodium. On the other hand, the olefinic proton at $\delta 5.84 \mathrm{ppm}$ correlates with a carbon at $\delta 131.2 \mathrm{ppm}$ in the ${ }^{1} \mathrm{H}-{ }^{13} \mathrm{C}$ HSQC spectrum and with a $=\mathrm{CH}$ - doublet at $126.2\left(J_{\mathrm{Rh}-\mathrm{C}}=39.4 \mathrm{~Hz}\right)$ in the ${ }^{1} \mathrm{H}-{ }^{13} \mathrm{C} \mathrm{HMBC}$ spectrum, which confirms the nature of the $\eta^{1}-6$-alkenyl moiety in 13 . Heating of the mixture led to the formation of the vinyl sulfides resulting from C-S coupling. These results are in sharp contrast with those previously observed for the intermediate species $\mathrm{RhHCl}(\mathrm{SPh})(\mathrm{IPr})(\mathrm{py})^{16 \mathrm{a}}$ and $\mathrm{RhH}\left(\mathrm{SCH}_{2} \mathrm{Ph}\right)_{2}(\mathrm{IPr})(\mathrm{py})^{16 \mathrm{~b}}$ where addition of the alkyne led directly to the coupled vinyl sulfides without detecting any intermediate resulting for the alkyne insertion into the Rh-H bond.

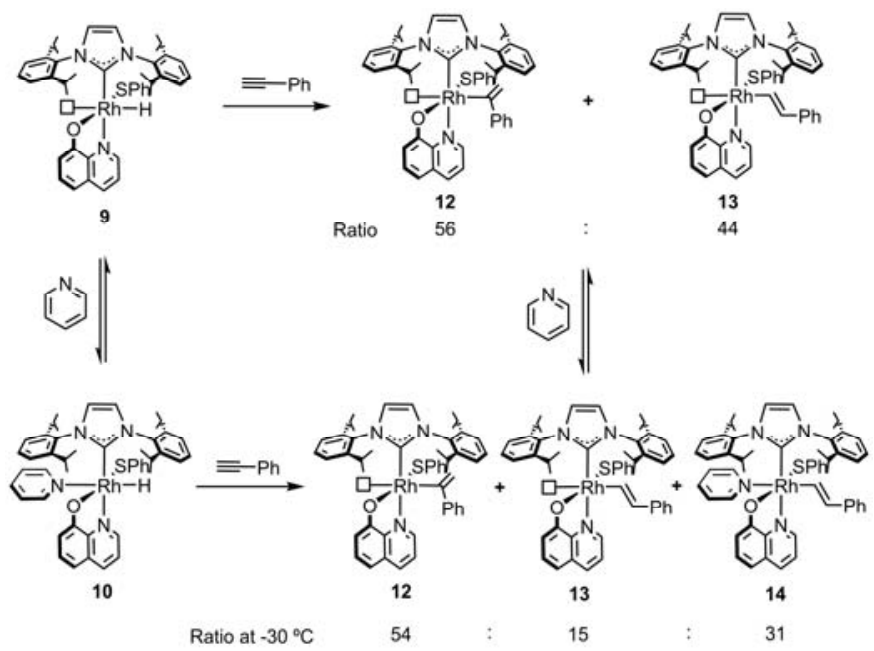

Scheme 6 . Reactivity of $\mathbf{9}$ and $\mathbf{1 0}$ with phenylacetylene.

In order to study the role of pyridine in the catalytic reaction, 3 equiv of this ligand were added to a NMR tube containing a mixture of 12 and 13 (Figure 8). A new octahedral species $\mathrm{Rh}\left(\eta^{1}-\mathrm{CH}=\mathrm{CHPh}\right)\left\{\kappa^{2}-\mathrm{O}, \mathrm{N}-\left(\mathrm{C}_{9} \mathrm{H}_{6} \mathrm{NO}\right)\right\}(\mathrm{SPh})(\mathrm{IPr})(\mathrm{py})$ (14) resulting from the coordination of pyridine to 13 was detected, but coordination of pyridine to $\mathbf{1 2}$ was not observed. The ${ }^{1} \mathrm{H}$ NMR spectrum of 14 displays two doublets at $\delta 8.90\left(J_{\mathrm{H}-\mathrm{H}}=5.2 \mathrm{~Hz}\right)$ and $8.62 \mathrm{ppm}\left(\mathrm{J}_{\mathrm{H}-\mathrm{H}}=4.5 \mathrm{~Hz}\right)$ corresponding to $\mathrm{H}(2)$ of pyridine and quinolinolate ligands, respectively. The two doublets at 
8.76 and $7.39 \mathrm{ppm}$, with a mutual coupling of $15.8 \mathrm{~Hz}$, were ascribed to $\mathrm{CH}$ protons of the $\eta^{1}-6-E$-alkenyl ligand. The 12:13:14 ratio was $54: 15: 31$ at $-30{ }^{\circ} \mathrm{C}$. The coordination of pyridine to 13 is reversible. Thus, the ratio 12:13:14 changed to $56: 36: 8$ at $20{ }^{\circ} \mathrm{C}$. Indeed, exchange peaks between the protons of the $\eta^{1}-6-E$-alkenyl ligands of 13 and 14 were observed in a ${ }^{1} \mathrm{H}$ 1D-NOESY experiment (See SI). Noteworthy, the same mixture of species was obtained after the addition of the reagents in the reverse order. Finally, heating of the mixture gave predominantly rise to the formation of gem-vinyl sulfide.
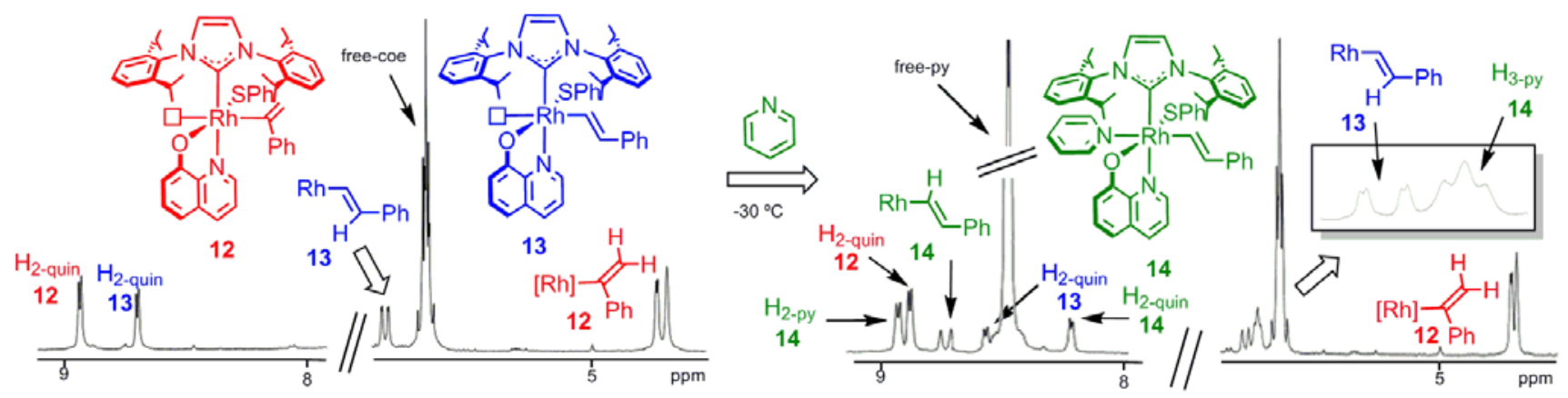

Figure 8. Representative regions of the ${ }^{1}$ H NMR spectra for in situ preparation of $\mathbf{1 2}$ and $\mathbf{1 3}$ and subsequent pyridine addition to form $\mathbf{1 4 .}$

The fact that pyridine coordinates trans to the hydride $(9)$ and 6 alkenyl (13) complexes but not to ethyl (11) or $\alpha$-alkenyl (12) derivatives is intriguing. The origin of this discrepancy may arise from electronic or steric reasons. However, the electronic effects do not seem to be relevant as the trans influence of the hydride is higher than the ethyl ligand. ${ }^{33}$ Thus, this behaviour might be rationalized on steric grounds. The DFT-optimized structures for the coordination of pyridine in these complexes nicely agree with the experimental observations (Figure 9). Pyridine coordination in $\mathbf{1 1}$ and 12 result in a destabilization by 4.3 and $1.5 \mathrm{kcal} \mathrm{mol}^{-1}$, respectively, whereas it is favoured in 9 and 13 by 12.0 and $2.9 \mathrm{kcal}$ $\mathrm{mol}^{-1}$, respectively. The steric influence of the ligand trans to vacant site is reflected in the bending of imidazole ring of the IPr with regard to the $\mathrm{Rh}-\mathrm{IPr}$ axis, described as the yaw angle $(\psi) .{ }^{34}$ The values of $6.77^{\circ}$ for $\mathbf{1 1}$ and $0.49^{\circ}$ for $\mathbf{9}$ are in agreement with the highest steric hindrance imparted by the ethyl ligand, forcing the IPr to bend to the vacant site and consequently hampering coordination of the pyridine. The $\psi$ angle for the $\alpha$-alkenyl complex 12 is $5.95^{\circ}$, slightly higher than that observed for the $b$-alkenyl derivative $13\left(5.05^{\circ}\right)$, suggesting the interplay of electronic and steric factors in this case. A similar steric effect has been observed in similar $d^{6}$-NHC-ruthenium olefin metathesis precursors. Thus, whereas pyridine coordinates into the benzylidene species $\mathrm{RuCl}_{2}$ (SIMes) $(=\mathrm{CHPh})(\mathrm{py})^{13} \quad(\mathrm{SIMes}=2,4,6-$ (trimethylphenyl)imidazolidin-2-carbene), it does not in $\mathrm{RuCl}_{2}$ (SIMes)(Ind)(py) $)^{35}$ bearing the bulkier indenylidene (Ind) ligand

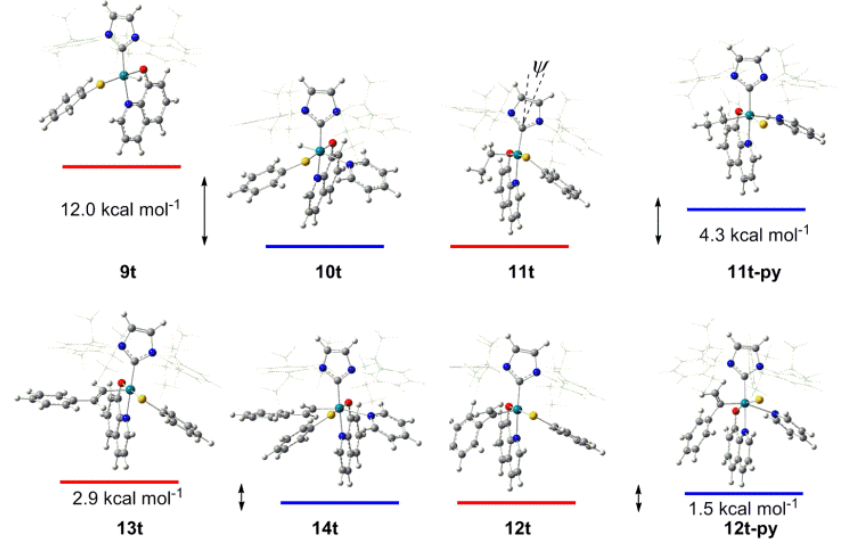

Figure 9. DFT-optimized ground state minimum energy structures for the coordination of pyridine to $\mathbf{9 , 1 1 , 1 2}$ and 13 .

Based on the above data, the mechanism depicted in Scheme 7 can be proposed for the formation of $\alpha$-vinyl sulfide. The first step is the release of olefin and oxidative addition of thiol to the $\mathrm{Rh}^{\prime}$ quinolinolate precursors to form an unsaturated hydride-thiolate$\mathrm{Rh}^{\text {III }}$ intermediate similar to 9. From this point two pathways are available. Cycle $a$ starts with an isomerization of the precursor and subsequent fast 2,1-insertion into the $\mathrm{Rh}-\mathrm{H}$ bond to generate an $\alpha$ alkenyl intermediate. Slow reductive elimination yields the C-S coupled product. Although generally a 1,2 insertion of alkynes into $\mathrm{M}-\mathrm{H}$ bonds is preferred, Markovnikov addition has been also observed. ${ }^{36}$ Alternatively, pathway $b$ starts by a slow 1,2-insertion of the alkyne into the Rh-thiolate bond, followed by fast $\mathrm{C}-\mathrm{H}$ reductive elimination. It was disclosed previously that pathway $b$ is operative for the catalytic systems $\left[\mathrm{Rh}(\mu-\mathrm{X})(\mathrm{NHC})\left(\eta^{2} \text {-olefin) }\right]_{2} / \mathrm{py}(\mathrm{X}\right.$ $=\mathrm{Cl}, \mathrm{OH}) .{ }^{16}$ Although this route cannot be excluded for rhodium quinolinolate-based catalysts, the detection of alkenyl intermediates strongly suggests a hydrometallation pathway in this case. 


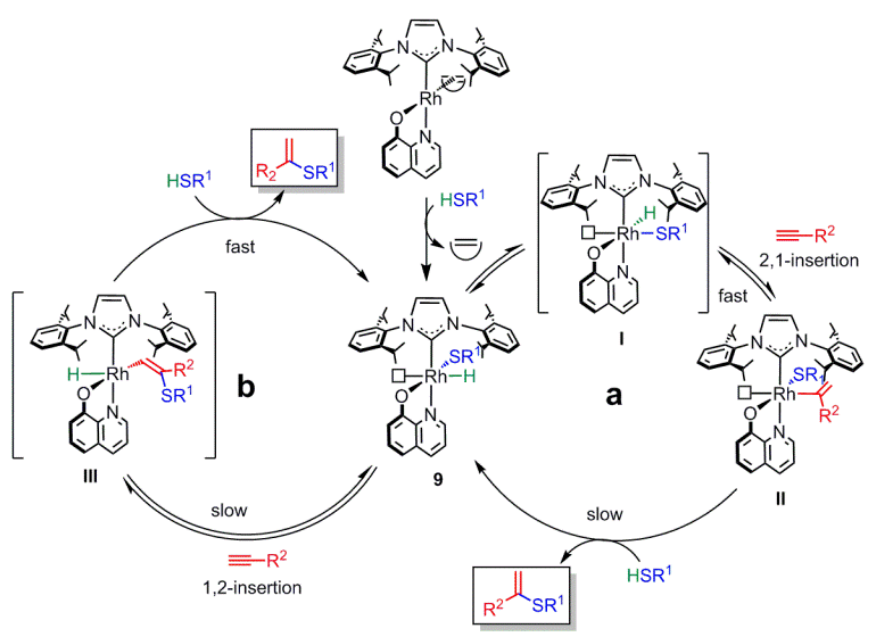

Scheme 7. Mechanistic pathways for the formation of $\alpha$-vinyl sulfide: a) hydride insertion, b) thiolate insertion.

\section{Theoretical Calculations on the Mechanism}

In order to discriminate between the two mechanistic pathways showed in Scheme 7, a detailed DFT computational study has been performed using B3LYP method including dispersion correction (Figure 10). Noteworthy, theoretical calculations dealing with alkyne hydrothiolation are scarce. $^{16,5 q, 37}$ Full IPr, quinolinolate, thiophenol and phenylacetylene have been explicitly considered. The starting point is $\mathrm{RhH}\left\{\kappa^{2}-\mathrm{O}, \mathrm{N}-\left(\mathrm{C}_{9} \mathrm{H}_{6} \mathrm{NO}\right)\right\}(\mathrm{SPh})(\mathrm{IPr})$ (A, compound 9), resulting from $\mathrm{S}-\mathrm{H}$ oxidative addition to $\mathrm{Rh}^{\prime}$ precursors. All energies are relative to $\mathbf{A}$ and the corresponding reactants. Both hydrometallation (right) or thiometallation (left) pathways have been computed.

The first step in both pathways is the coordination of the alkyne into $\mathbf{A}$. Thus, coordination of phenylacetylene trans to the hydride of $A$ with the two possible orientations results in a stabilization of $2.3(\mathbf{G})$ and $3.1 \mathrm{kcal} \mathrm{mol}^{-1}\left(\mathbf{G}^{\prime}\right)$. However, in order to hydrometallation pathway to proceed, the hydride and the $\pi$-alkyne have to be disposed mutually cis, therefore the minima $B$ and $B^{\prime}$ were computed, which are destabilized by 9.2 and $2.0 \mathrm{kcal} \mathrm{mol}^{-1}$, respectively. Then, insertion step via the hydrometallation pathway takes place through the transition states C-TS, for the branched alkenyl, and C'-TS for the linear one, located 9.9 and $10.3 \mathrm{kcal} \mathrm{mol}^{-1}$, higher than $\mathbf{A}$, respectively. The pathway evolves to intermediates $\mathbf{D}$ and $\mathbf{D}^{\prime}$, which lay at -18.7 and $-29.9 \mathrm{kcal} \mathrm{mol}^{-1}$, respectively.
Noteworthy, the transition states C-TS and C'-TS are more stable than those corresponding to thiometalation pathways, H-TS and $\mathbf{H}^{\prime}$-TS (17.6 and $21.2 \mathrm{kcal} \mathrm{mol}^{-1}$ ), in spite of the connected $\pi$-alkyne minima $\mathbf{G}$ and $\mathbf{G}^{\prime}$ are lower in energy than B and B'.

The next step is the reductive elimination starting from $\mathbf{D}$ and $\mathbf{D}^{\prime}$ to give $\mathbf{F}$ and $\mathbf{F}^{\prime}$, respectively, that display the same activation barrier of $28.1 \mathrm{kcal} \mathrm{mol}^{-1}$ for branched and linear vinyl sulfides via E-TS and E'-TS. The high energy barriers for the reductive elimination step through the hydrometallation pathway open the possibility for $\mathbf{D}$ and $\mathbf{D}^{\prime}$ 'species to revert into $\mathbf{A}$ to follow the thiometallation route that show lower energetic barrier for the reductive elimination (13.2 and 16.2

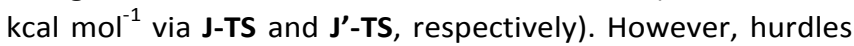
of 36.3 and $51.1 \mathrm{kcal} \mathrm{mol}^{-1}$ have to be surpassed from $\mathbf{D}$ and $D^{\prime}$ to $\mathbf{H}-\mathbf{T S}$ and $\mathbf{H}^{\prime}$-TS.

The calculations indicate that reductive elimination is the rate-determining step for both Markovnikov and antiMarkovnikov additions, displaying the same activation barrier $\left(28.1 \mathrm{kcal} \mathrm{mol}^{-1}\right)$. At this point the selectivity is governed by the energy difference between the transition states for the insertion step C-TS and $\mathbf{C}^{\prime}$-TS of only $0.4 \mathrm{kcal} \mathrm{mol}^{-1}$. This result does not match well with the $74-80 \%$ of regioselectivity attained in the absence of pyridine. However, thiophenol is in excess under catalytic conditions, so it can bind to the pentacoordinated Rh-alkenyl species. Computation of the thiol coordination to $\mathbf{D}$ and $\mathbf{D}^{\prime}$ shows that the linear alkenyl complex $\mathbf{D}^{\prime}$-HSPh is stabilized by $0.8 \mathrm{kcal} \mathrm{mol}^{-1}$, whereas the branched alkenyl complex D-HSPh is destabilized by $1.2 \mathrm{kcal}$ $\mathrm{mol}^{-1}$. The activation barrier for the reductive elimination step leading to the formation of linear vinyl sulfide is now 0.8 kcal $\mathrm{mol}^{-1}$ higher, therefore explaining the moderate Markovnikov selectivity observed in the absence of pyridine.

In order to explain the positive pyridine effect found in this catalytic system, the coordination of pyridine to $\mathbf{D}$ and $\mathbf{D}^{\prime}$ was also computed. Remarkably, the $\mathbf{B}$-alkenyl complex $\mathbf{D}^{\prime}$-py is stabilized by $2.9 \mathrm{kcal} \mathrm{mol}^{-1}$, whereas D-py lays $1.5 \mathrm{kcal} \mathrm{mol}^{-1}$ higher. The difference of almost $3 \mathrm{kcal} \mathrm{mol}^{-1}$ gained by the coordination of pyridine perfectly explains the observed selectivity (Figure 11). Although pyridine is ubiquitous as additive in many catalytic transformations, ${ }^{7-14}$ its role has not always been clearly established. Here, the interplay of stereolectronic properties within Rh-IPr species determines the coordination or not of pyridine in the key alkenyl intermediates. The coordination of pyridine in the 6 -alkenyl complex results in a net stabilization of this species decreasing the catalytic activity. However, the $\alpha$ alkenyl intermediate is not influenced by the pyridine ligand and, as a consequence, an increment of the $\alpha$-vinyl sulfide product is observed. 


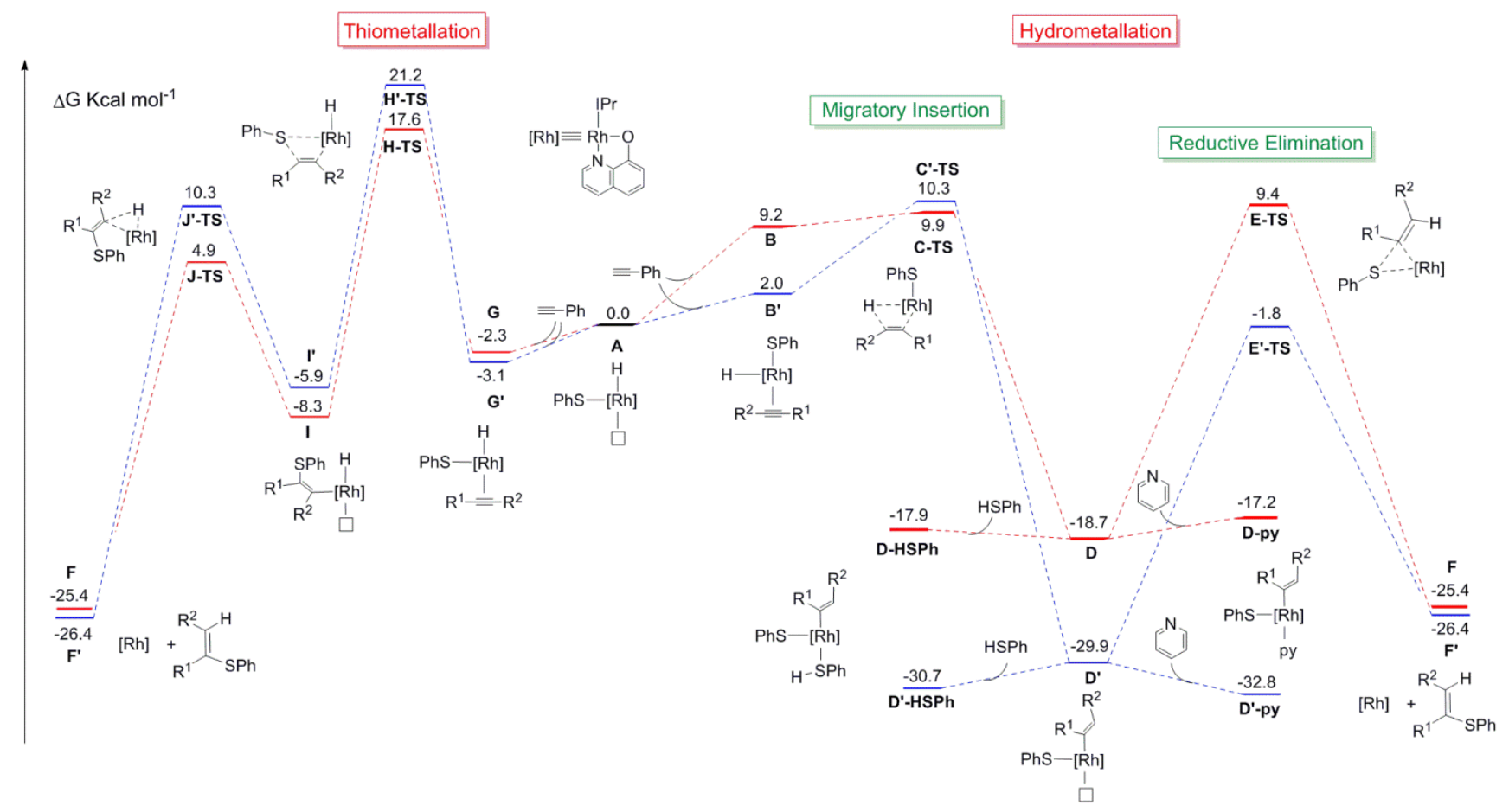

Figure 10. DFT calculated $\left(\Delta \mathrm{G}\right.$ in $\mathrm{kcal} \mathrm{mol}^{-1}$ ) along the energy surface for the formation of vinyl sulfides through thiometallation and hydrometallation. Structures $\mathbf{B}$ to $\mathbf{F}$ correspond to $\alpha$-vinyl sulfide $\left(R^{1}=P h, R^{2}=H\right.$, red line) and structures $\mathbf{B}^{\prime}$ to $\mathbf{F}^{\prime}$ lead to $B$-vinyl sulfides $\left(R^{1}=H, R^{2}=P h\right.$, blue line).

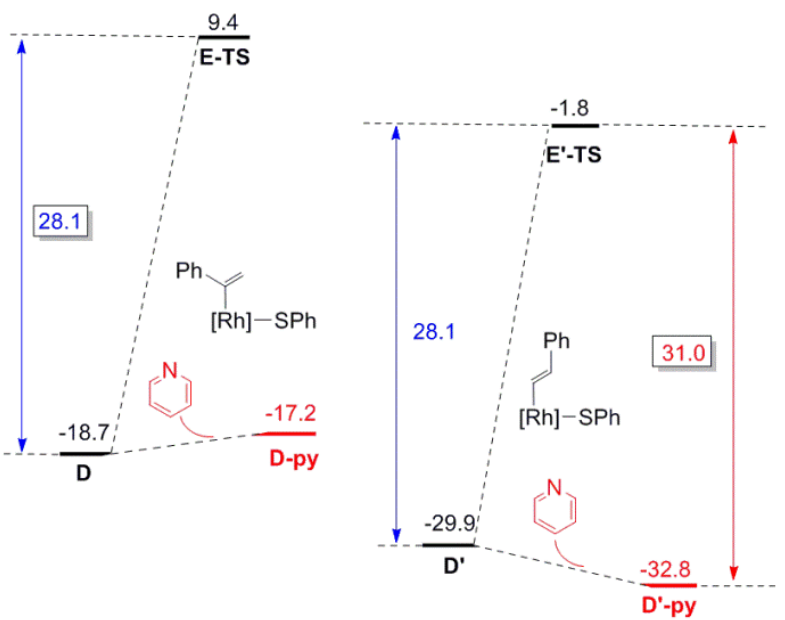

Figure 11. Pyridine effect over the reductive elimination energy barriers through the hydrometallation pathway.

\section{Conclusions}

In summary, new $\mathrm{Rh}^{\prime}-\mathrm{NHC}$-olefin derivatives bearing a $\mathrm{N}, \mathrm{O}-$ quinolinolate bidentate ligand are efficient catalysts for the addition of thiophenol to phenylacetylene with good selectivity towards the Markovnikov product. It has been found that selectivity can be increased up to $97 \%$ by using pyridine as additive. Reactivity studies involving the sequential reaction of the precatalysts with thiophenol, phenylacetylene and pyridine have revealed the role of the pyridine in the selectivity of alkyne hydrothiolation. Addition of thiophenol to the metal complex gives a $\mathrm{Rh}^{\prime \prime \prime}-\mathrm{H}$ unsaturated derivative, as a result of the $\mathrm{S}-\mathrm{H}$ oxidative addition. Further reaction with phenylacetylene affords key

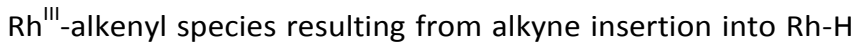
bond. The particular stereolectronic properties within the pentacoordinated intermediates result in a different behaviour towards pyridine. It has been observed that pyridine binds to the $\eta^{1}-6$-alkenyl species but not to the bulkier $\eta^{1}$ - $\alpha$-alkenyl which is also supported by theoretical calculations. The full theoretical analysis of both hydrometallation and thiometallation pathways supports a hydrometallation mechanism that is in full agreement with the experimental results. The preferred pathway starts by oxidative addition of the thiol and subsequent 2,1-insertion of the alkyne into the $\mathrm{Rh}-\mathrm{H}$ bond with the reductive elimination as rate-determining step. Remarkably, the coordination of pyridine to the $B$-alkenyl intermediate, which results in a net stabilization, but not to the $\alpha$-alkenyl determines the Markovnikov selectivity. We hope that the understanding of the pyridine effect in this catalytic system will be helpful for the design of new pyridine-based catalytic precursors for other useful transformations. 


\section{Experimental Section}

General Considerations. All reactions were carried out with rigorous exclusion of air using Schlenk-tube techniques. The reagents were purchased from commercial sources and were used as received, except for phenylacetylene that was distilled and stored over molecular sieves. Organic solvents were dried by standard procedures and distilled under argon prior to use or obtained oxygen- and water-free from a Solvent Purification System (Innovative Technologies). The organometallic precursors $\mathbf{3}$ and $\mathbf{4}$ were prepared as previously described. ${ }^{16 \mathrm{~b}}$ Chemical Shifts (expressed in parts per million) are referenced to residual solvent peaks $\left({ }^{1} \mathrm{H}\right.$, $\left.{ }^{13} \mathrm{C}\left\{{ }^{1} \mathrm{H}\right\}\right)$ or liquid $\mathrm{NH}_{3}\left({ }^{15} \mathrm{~N}\right)$. Coupling constants, $J$, are given in $\mathrm{Hz}$. Spectral assignments were achieved by combination of ${ }^{1} \mathrm{H}-{ }^{1} \mathrm{H} \quad \mathrm{COSY}, \quad{ }^{13} \mathrm{C}\left\{{ }^{1} \mathrm{H}\right\}-\mathrm{APT}$ and ${ }^{1} \mathrm{H}-{ }^{13} \mathrm{C} \quad \mathrm{HSQC} / \mathrm{HMBC}$ experiments. $\mathrm{H}, \mathrm{C}$ and $\mathrm{N}$ analysis were carried out in a PerkinElmer $2400 \mathrm{CHNS/O}$ analyzer. GC-MS analysis were recorder on an Agilent 5973 mass selective detector interfaced to an Agilent 6890 series gas chromatograph system, using a HP$5 \mathrm{MS} 5 \%$ phenyl methyl siloxane column $(30 \mathrm{~m} \times 250 \mathrm{~mm}$ with a $0.25 \mathrm{~mm}$ film thickness).

Preparation of $\mathrm{Rh}\left\{\kappa^{2}-\mathrm{O}, \mathrm{N}-\left(\mathrm{C}_{9} \mathrm{H}_{6} \mathrm{NO}\right)\right\}\left(\eta^{2}-\mathrm{coe}\right)(\mathrm{IPr})$ (5). A yellow solution of $\mathbf{3}(100 \mathrm{mg}, 0.081 \mathrm{mmol})$ in toluene $(10 \mathrm{~mL})$ was treated with 8-hydroxyquinoline $(23 \mathrm{mg}, 0.16 \mathrm{mmol}$ ) and stirred for $2 \mathrm{~h}$ at room temperature to give a tile red solution. Then, the solution was concentrated to ca. $1 \mathrm{~mL}$ and $n$ hexane added to induce the precipitation of a tile red solid, which was washed with $n$-hexane $(3 \times 3 \mathrm{~mL})$ and dried in vacuo. Yield: $92 \mathrm{mg}$ (76\%). The compound was obtained as two structural isomers $\mathbf{5 a}$ and $\mathbf{5 b}$ in a 55:45 ratio. HRMS (ESI) $\mathrm{m} / \mathrm{z}$ calcd for $\mathrm{RhC}_{36} \mathrm{H}_{41} \mathrm{~N}_{3} \mathrm{O}(\mathrm{M}-\mathrm{coe}-\mathrm{H})^{+} 634.2299$ found 634.2270. 5a (N-trans-IPr): ${ }^{1} \mathrm{H}$ NMR (400 MHz, $\left.\mathrm{C}_{6} \mathrm{D}_{6}, 298 \mathrm{~K}\right): \delta$ $8.33\left(\mathrm{~d}, J_{\mathrm{H}-\mathrm{H}}=4.9,1 \mathrm{H}, \mathrm{H}_{2 \text {-quin }}\right), 7.44\left(\mathrm{~d}, J_{\mathrm{H}-\mathrm{H}}=8.2,1 \mathrm{H}, \mathrm{H}_{4 \text {-quin }}\right)$, 7.3-7.0 (m, 7H, $\left.\mathrm{H}_{\mathrm{Ph}-\mathrm{Pr},}, \mathrm{H}_{6 \text {-quin }}\right), 6.99\left(\mathrm{~d}, J_{\mathrm{H}-\mathrm{H}}=7.6,1 \mathrm{H}, \mathrm{H}_{7 \text {-quin }}\right)$, $6.60\left(\mathrm{~d}, J_{\mathrm{H}-\mathrm{H}}=7.2,1 \mathrm{H}, \mathrm{H}_{5 \text {-quin }}\right), 6.52(\mathrm{~s}, 2 \mathrm{H},=\mathrm{CHN}), 6.31\left(\mathrm{dd}, J_{\mathrm{H}-}\right.$ $\left.\mathrm{H}=8.2,4.9,1 \mathrm{H}, \mathrm{H}_{3 \text {-quin }}\right), 3.04\left(\mathrm{~m}, 2 \mathrm{H},=\mathrm{CH}_{\text {coe }}\right), 2.26$ (sept, $J_{\mathrm{H}-\mathrm{H}}=$ 6.7, $\left.4 \mathrm{H}, \mathrm{CHMe}_{\mathrm{IPr}}\right), 2.1-1.7\left(\mathrm{~m}, 12 \mathrm{H}, \mathrm{CH}_{2-\mathrm{coe}}\right), 1.37$ and 0.97 (both d, $J_{\mathrm{H}-\mathrm{H}}=6.7,24 \mathrm{H}, \mathrm{CHM} \underline{\mathrm{Me}}_{\mathrm{Pr}}$ ). ${ }^{13} \mathrm{C}\left\{{ }^{1} \mathrm{H}\right\}$-APT NMR (100.6 $\left.\mathrm{MHz}, \mathrm{C}_{6} \mathrm{D}_{6}, 298 \mathrm{~K}\right): \delta 193.0\left(\mathrm{~d}, J_{\mathrm{C}-\mathrm{Rh}}=59.2, \mathrm{Rh}-\mathrm{C}_{\text {IPr }}\right), 170.5(\mathrm{~s}$, $\mathrm{C}_{\text {8-quin }}$ ), 147.9 (s, $\mathrm{C}_{\text {2-quin }}$ ), 146.6 (s, $\mathrm{C}_{\text {q-IPr }}$ ), 144.8 (s, $\mathrm{C}_{\text {8a-quin }}$ ), $137.0\left(\mathrm{~s}, \mathrm{C}_{\mathrm{q}} \mathrm{N}\right), 136.1$ (s, $\left.\mathrm{C}_{4-\text { quin }}\right), 128-123\left(\mathrm{CH}_{\mathrm{Ph}-\mathrm{Pr}}\right), 130.8$ (s, $\mathrm{C}_{4 \mathrm{a} \text {-quin }}$ ), 128.0 (s, $\mathrm{C}_{6 \text {-quin }}$ ), 124.2 (s, =CHN), 119.4 (s, $\mathrm{C}_{3 \text {-quin }}$ ), 114.9 (s, $\left.C_{7-\text { quin }}\right), 106.7$ (s, $\left.\mathrm{C}_{5 \text {-quin }}\right), 55.3\left(\mathrm{~d}, \mathrm{~J}_{\mathrm{C}-\mathrm{Rh}}=15.4,=\mathrm{CH}_{\text {coe }}\right)$, 30.6, 29.4, and 27.0 (all s, $\mathrm{CH}_{2-\text { coe }}$ ), 28.6 (s, $\underline{\mathrm{C}} \mathrm{HMe}_{\mathrm{IPr}}$ ), 26.6 and 22.9 (both s, $\left.\mathrm{CHMe}_{\mid \mathrm{Pr}}\right) .{ }^{1} \mathrm{H}-{ }^{15} \mathrm{~N}$ NMR HMBC $(50.7 \mathrm{MHz}$, toluene- $\left.d_{8}, 243 \mathrm{~K}\right): \delta 248.3\left(\mathrm{~N}_{\text {quin }}\right), 192.9\left(\mathrm{~N}_{\mathrm{IPr}}\right) .5 \mathrm{~b}(\mathrm{~N}-$ cis-IPr): ${ }^{1} \mathrm{H}$ NMR $\left(400 \mathrm{MHz}, \mathrm{C}_{6} \mathrm{D}_{6}, 298 \mathrm{~K}\right): \delta 7.84\left(\mathrm{~d}, \mathrm{~J}_{\mathrm{H}-\mathrm{H}}=4.5,1 \mathrm{H}, \mathrm{H}_{2-}\right.$ quin), $7.72\left(\mathrm{dd}, J_{\mathrm{H}-\mathrm{H}}=8.3,1.3,1 \mathrm{H}, \mathrm{H}_{4-\text { quin }}\right), 7.48$ (dd, $J_{\mathrm{H}-\mathrm{H}}=8.5$, 7.1, $\left.1 \mathrm{H}, \mathrm{H}_{6 \text {-quin }}\right), 7.3-7.1\left(\mathrm{~m}, 7 \mathrm{H}, \mathrm{H}_{\mathrm{Ph}-\mathrm{PPr}}, \mathrm{H}_{7 \text {-quin }}\right), 6.70(\mathrm{~s}, 2 \mathrm{H}$, $=C H N), 6.67\left(\mathrm{~d}, J_{\mathrm{H}-\mathrm{H}}=7.1,1 \mathrm{H}, \mathrm{H}_{5-\text { quin }}\right), 6.61\left(\mathrm{dd}, J_{\mathrm{H}-\mathrm{H}}=8.3,4.5\right.$, $\left.1 \mathrm{H}, \mathrm{H}_{3 \text {-quin }}\right), 3.69$ (sept, $\left.J_{\mathrm{H}-\mathrm{H}}=6.8,4 \mathrm{H}, \mathrm{C} \mathrm{HMe}_{\mathrm{IPr}}\right), 3.44(\mathrm{~m}, 2 \mathrm{H}$, $\left.=\mathrm{CH}_{\text {coe }}\right), 2.73,1.89$, and 1.44 (all $\mathrm{m}, 12 \mathrm{H}, \mathrm{CH}_{2 \text {-coe }}$ ), 1.03 and 0.56 (both d, $J_{\mathrm{H}-\mathrm{H}}=6.8,24 \mathrm{H}, \mathrm{CHM} \underline{\mathrm{M}}_{\mid \mathrm{Pr}}$ ). ${ }^{13} \mathrm{C}\left\{{ }^{1} \mathrm{H}\right\}-\mathrm{APT}$ NMR $\left(100.6 \mathrm{MHz}, \mathrm{C}_{6} \mathrm{D}_{6}, 298 \mathrm{~K}\right): \delta 184.7\left(\mathrm{~d}, \mathrm{~J}_{\mathrm{C}-\mathrm{Rh}}=56.2 \mathrm{Rh}-\mathrm{C}_{\mathrm{IPr}}\right)$, 171.0 (s, $\left.C_{8 \text {-quin }}\right), 146.1$ (s, $\left.C_{\text {q-IPr }}\right), 146.0$ (s, $\left.C_{\text {2-quin }}\right), 147.0$ (s, $C_{8 a-}$ quin), $137.2\left(\mathrm{~s}, \mathrm{C}_{4-\text { quin }}\right), 137.1\left(\mathrm{~s}, \mathrm{C}_{\mathrm{q}} \mathrm{N}\right), 128-123\left(\mathrm{CH}_{\mathrm{Ph}-\mathrm{Pr}}\right), 131.1$ (s, $\mathrm{C}_{4 a-q u i n}$ ), 129.5 (s, $\mathrm{C}_{6 \text {-quin }}$ ), 124.7 (s, =CHN), 118.7 (s, $\mathrm{C}_{3 \text {-quin }}$ ), 113.6 (s, $\left.C_{7-\text { quin }}\right), 109.3\left(\mathrm{~s}, \mathrm{C}_{5 \text {-quin }}\right), 65.9\left(\mathrm{~d}, \mathrm{~J}_{\mathrm{C}-\mathrm{Rh}}=15.0,=\mathrm{CH}_{\text {coe }}\right.$ ), 30.5, 28.1, and 26.6 (all s, $\mathrm{CH}_{2-\text { coe }}$ ), 28.7 (s, $\underline{\mathrm{C}} \mathrm{HMe}_{\mathrm{IPr}}$ ), 25.4 and 22.2 (both s, $\mathrm{CHMe}_{\mid \mathrm{Pr}}$ ). ${ }^{1} \mathrm{H}-{ }^{15} \mathrm{~N}$ NMR HMBC $(50.7 \mathrm{MHz}$, toluene- $\left.d_{8}, 243 \mathrm{~K}\right)$ : $\delta 252.8\left(\mathrm{~N}_{\text {quin }}\right), 192.6\left(\mathrm{~N}_{\mathrm{IPr}}\right)$.

Preparation of $\mathrm{Rh}\left\{\kappa^{2}-\mathrm{O}, \mathrm{N}-\left(\mathrm{C}_{9} \mathrm{H}_{6} \mathrm{NO}\right)\right\}(\mathrm{IPr})\left(\eta^{2}-\mathrm{CH}_{2}=\mathrm{CH}_{2}\right)(\mathrm{IPr})$ (6). The complex was prepared as described for 5 starting from 4 (78 $\mathrm{mg}, 0.073 \mathrm{mmol}$ ) and 8-hydroxyquinoline $(21 \mathrm{mg}$, $0.14 \mathrm{mmol}$ ) and obtained as an orange solid. Yield: $69 \mathrm{mg}$ (71\%). Anal. Calcd. for $\mathrm{C}_{38} \mathrm{H}_{46} \mathrm{~N}_{3} \mathrm{ORh} . \mathrm{H}_{2} \mathrm{O}: \mathrm{C}, 66.95 ; \mathrm{H}, 7.10 ; \mathrm{N}$, 6.16. Found: $\mathrm{C}, 66.54 ; \mathrm{H}, 7.02 ; \mathrm{N}, 6.22 .{ }^{1} \mathrm{H}$ NMR $(300 \mathrm{MHz}$, $\left.\mathrm{C}_{6} \mathrm{D}_{6}, 298 \mathrm{~K}\right): \delta 7.46\left(\mathrm{dd}, J_{\mathrm{H}-\mathrm{H}}=7.9,7.9,1 \mathrm{H}, \mathrm{H}_{6 \text {-quin }}\right), 7.33(\mathrm{dd}$, $\left.J_{\mathrm{H}-\mathrm{H}}=8.3,1.0,1 \mathrm{H}, \mathrm{H}_{4-\text { quin }}\right), 7.21$ (dd, $\left.J_{\mathrm{H}-\mathrm{H}}=7.9,1.0,1 \mathrm{H}, \mathrm{H}_{5-\text { quin }}\right)$, 7.2-7.1 (6H, $\left.\mathrm{H}_{\mathrm{Ph}-\mathrm{Pr}}\right), 6.77\left(\mathrm{dd}, J_{\mathrm{H}-\mathrm{H}}=4.9,1.0,1 \mathrm{H}, \mathrm{H}_{2 \text {-quin }}\right), 6.64$ $\left(\mathrm{dd}, J_{\mathrm{H}-\mathrm{H}}=7.9,1.0,1 \mathrm{H}, \mathrm{H}_{7 \text {-quin }}\right), 6.19\left(\mathrm{dd}, J_{\mathrm{H}-\mathrm{H}}=8.3,4.9,1 \mathrm{H}, \mathrm{H}_{3-}\right.$ quin), $6.60\left(\mathrm{~s}, 2 \mathrm{H},=\mathrm{CHN}\right.$ ), 3.44 (sept, $J_{\mathrm{H}-\mathrm{H}}=6.8,4 \mathrm{H}, \mathrm{CHMe}_{\mathrm{IPr}}$ ), $2.31\left(\mathrm{br}, 4 \mathrm{H}, \mathrm{CH}_{2}=\mathrm{CH}_{2}\right.$ ), 1.54 and 1.13 (both d, $J_{\mathrm{H}-\mathrm{H}}=6.8,24 \mathrm{H}$, $\mathrm{CHMe}_{\mid \mathrm{Pr}}$ ). ${ }^{13} \mathrm{C}\left\{{ }^{1} \mathrm{H}\right\}$-APT NMR (75.1 $\left.\mathrm{MHz} \mathrm{C}_{6} \mathrm{D}_{6}, 298 \mathrm{~K}\right): \delta 186.8$ $\left(\mathrm{d}, J_{\mathrm{C}-\mathrm{Rh}}=56.7, \mathrm{Rh}-\mathrm{C}_{\mathrm{IPr}}\right), 171.3\left(\mathrm{~s}, \mathrm{C}_{8-\text { quin }}\right), 146.6\left(\mathrm{~s}, \mathrm{C}_{\mathrm{q}-\mathrm{PPr}}\right), 145.2$ (s, $\left.\mathrm{C}_{\text {8a-quin }}\right), 140.4\left(\mathrm{~s}, \mathrm{C}_{\text {2-quin }}\right), 136.8\left(\mathrm{~s}, \mathrm{C}_{\mathrm{q}} \mathrm{N}\right), 134.8\left(\mathrm{~s}, \mathrm{C}_{\text {4-quin }}\right)$, 130.2 (s, $\left.\mathrm{C}_{4 \mathrm{a} \text {-quin }}\right), 130.0\left(\mathrm{~s}, \mathrm{C}_{6 \text {-quin }}\right), 124.0(\mathrm{~s},=\mathrm{CHN}$ ), 129.5 and 123.8 (both s, $\mathrm{CH}_{\mathrm{Ph}-\mathrm{Pr}}$ ), 119.9 (s, $\mathrm{C}_{3 \text {-quin }}$ ), 112.7 (s, $\mathrm{C}_{5 \text {-quin }}$ ), 109.1 (s, C $\mathrm{C}_{\text {7-quin }}$ ), 36.6 (d, $J_{\mathrm{C}-\mathrm{Rh}}=16.2, \mathrm{CH}_{2}=\mathrm{CH}_{2}$ ), 28.7 (s, $\mathrm{CHMe}_{\mathrm{IPr}}$ ), 26.2 and 23.1 (both s, CHMe $\underline{\mathrm{IPr}}_{\mathrm{Pr}}$ ). ${ }^{1} \mathrm{H}-{ }^{15} \mathrm{~N}$ NMR HMBC $\left(50.7 \mathrm{MHz}\right.$, toluene- $\left.d_{8}, 298 \mathrm{~K}\right): \delta 253.3\left(\mathrm{~N}_{\text {quin }}\right), 191.9\left(\mathrm{~N}_{\mathrm{IPr}}\right)$.

In situ formation of $\mathrm{Rh}\left\{\kappa^{2}-\mathrm{O}, \mathrm{N}-\left[\mathrm{C}_{9} \mathrm{H}_{5} \mathrm{NO}\left(\mathrm{CH}_{3}\right)\right]\right\}\left(\eta^{2}-\mathrm{coe}\right)(\mathrm{IPr})$ (7). A toluene- $d_{8}$ solution of $3(30 \mathrm{mg}, 0.023 \mathrm{mmol})$ in an NMR tube at $233 \mathrm{~K}$ was treated with 2-methyl-8-hydroxyquinoline $(7.7 \mathrm{mg}, 0.047 \mathrm{mmol})$. NMR spectra were immediately recorded at low temperature. ${ }^{1} \mathrm{H}$ NMR (400 $\mathrm{MHz}$, toluene- $\left.d_{8}, 233 \mathrm{~K}\right): \delta 7.60\left(\mathrm{~d}, J_{\mathrm{H}-\mathrm{H}}=8.4,1 \mathrm{H}, \mathrm{H}_{4-\text { quin }}\right), 7.26$ (dd, $\left.J_{H-H}=8.5,7.2,1 \mathrm{H}, \mathrm{H}_{6 \text {-quin }}\right), 7.1-7.0\left(\mathrm{~m}, 7 \mathrm{H}, \mathrm{H}_{\text {Ph-IPr, }} \mathrm{H}_{7 \text {-quin }}\right)$, $6.63\left(\mathrm{~d}, J_{\mathrm{H}-\mathrm{H}}=8.5,1 \mathrm{H}, \mathrm{H}_{3 \text {-quin }}\right), 6.61\left(\mathrm{~d}, J_{\mathrm{H}-\mathrm{H}}=8.4,1 \mathrm{H}, \mathrm{H}_{5 \text {-quin }}\right)$, $6.40(\mathrm{~s}, 2 \mathrm{H},=\mathrm{CHN}), 4.14$ and 2.05 (both sept, $J_{\mathrm{H}-\mathrm{H}}=6.6,4 \mathrm{H}$, $\left.\mathrm{CHMe}_{\text {Ipr }}\right), 2.85\left(\mathrm{~m}, 2 \mathrm{H},=\mathrm{CH}_{\text {coe }}\right), 2.00\left(\mathrm{~s}, 3 \mathrm{H}, \mathrm{Me}_{\text {quin }}\right), 1.7-1.1$ (br, $12 \mathrm{H}, \mathrm{CH}_{2 \text {-coe }}$ ), 1.23, 1.00, 0.98, and 0.86 (all d, $J_{\mathrm{H}-\mathrm{H}}=6.6$, $\left.24 \mathrm{H}, \mathrm{CHMe} \underline{\mathrm{Ipr}}_{\mathrm{p}}\right) \cdot{ }^{13} \mathrm{C}\left\{{ }^{1} \mathrm{H}\right\}-\mathrm{APT}$ NMR $\left(100.6 \mathrm{MHz}\right.$, toluene- $d_{8}, 233$ $\mathrm{K}): \delta 196.4\left(\mathrm{~d}, J_{\mathrm{C}-\mathrm{Rh}}=52.3, \mathrm{Rh}-\mathrm{C}_{\text {|Pr }}\right), 170.2\left(\mathrm{~s}, \mathrm{C}_{8 \text {-quin }}\right), 146.5$ and 145.8 (both s, $\mathrm{C}_{\text {q-IPr }}$ ), 153.6 (s, $\mathrm{C}_{2 \text {-quin }}$ ), 146.1 (s, $\mathrm{C}_{8 \mathrm{a} \text {-quin }}$ ), 138.0 (s, $\mathrm{C}_{\text {4-quin }}$ ), $137.2\left(\mathrm{~s}, \mathrm{C}_{\mathrm{q}} \mathrm{N}\right.$ ), 128.4, 124.2, and 123.9 (all s, $\mathrm{CH}_{\mathrm{Ph}-}$ IPr), 129.2 (s, $\left.C_{4 a-q u i n}\right), 128.9$ (s, $\left.C_{6-\text { quin }}\right), 123.9$ (s, =CHN), 121.7 (s, $\left.\mathrm{C}_{3 \text {-quin }}\right), 115.9\left(\mathrm{~s}, \mathrm{C}_{7 \text {-quin }}\right), 107.2\left(\mathrm{~s}, \mathrm{C}_{5 \text {-quin }}\right), 61.2\left(\mathrm{~d}, J_{\mathrm{C}-\mathrm{Rh}}=\right.$ 16.9, $=\mathrm{CH}_{\text {coe }}$ ), 30.2, 27.7, and 26.8 (all s, $\mathrm{CH}_{2 \text {-coe }}$ ), 28.6 and 26.4 (both s, $\left.\underline{\mathrm{C}} \mathrm{HMe}_{\mid \mathrm{Pr}}\right), 28.4\left(\mathrm{Me}_{\text {quin }}\right), 26.1,25.8,24.0$, and 23.0 (all s, $\mathrm{CHMe}$ IPr).

Preparation of $\mathrm{Rh}\left\{\left(\kappa^{2}-\mathrm{O}, \mathrm{N}-\left[\mathrm{C}_{9} \mathrm{H}_{5} \mathrm{NO}\left(\mathrm{CH}_{3}\right)\right]\right\}\left(\eta^{2}-\mathrm{CH}_{2}=\mathrm{CH}_{2}\right)(\mathrm{IPr})\right.$ (8). A yellow solution of 4 (100 $\mathrm{mg}, 0.081 \mathrm{mmol})$ in toluene (5 $\mathrm{mL}$ ) was treated with 2-methyl-8-hydroxy-quinoline $(26 \mathrm{mg}$, $0.16 \mathrm{mmol}$ ) and stirred for $1 \mathrm{~h}$ at room temperature to give an orange solution. Then, the solution was concentrated to ca. $1 \mathrm{~mL}$ and $n$-hexane added to $-20{ }^{\circ} \mathrm{C}$ to induce the precipitation of an orange solid, which was washed with cold $n$-hexane $(3 \times 3 \mathrm{~mL})$ and dried in vacuo. Yield: $71 \mathrm{mg}(65 \%)$. Anal. Calcd. for $\mathrm{C}_{39} \mathrm{H}_{48} \mathrm{~N}_{3} \mathrm{ORh} .2 \mathrm{H}_{2} \mathrm{O}: \mathrm{C}, 65.62 ; \mathrm{H}, 7.34 ; \mathrm{N}, 5.88$. Found: $\mathrm{C}, 65.31 ; \mathrm{H}, 7.15 ; \mathrm{N}, 5.85 .{ }^{1} \mathrm{H} \mathrm{NMR}\left(400 \mathrm{MHz}, \mathrm{C}_{6} \mathrm{D}_{6}\right.$, $298 \mathrm{~K}$ ): $\delta 7.43\left(\mathrm{dd}, J=8.0,7.7,1 \mathrm{H}, \mathrm{H}_{6 \text {-quin }}\right), 7.28\left(\mathrm{~d}, J_{\mathrm{H}-\mathrm{H}}=8.3\right.$, $\left.1 \mathrm{H}, \mathrm{H}_{4 \text {-quin }}\right), 7.32\left(\mathrm{~d}, \mathrm{~J}_{\mathrm{H}-\mathrm{H}}=8.0,1 \mathrm{H}, \mathrm{H}_{7 \text {-quin }}\right), 7.2-7.0\left(\mathrm{~m}, 6 \mathrm{H}, \mathrm{H}_{\mathrm{Ph}-}\right.$ 
$(\operatorname{Pr}), 6.65\left(\mathrm{~d}, \mathrm{~J}_{\mathrm{H}-\mathrm{H}}=7.7,1 \mathrm{H}, \mathrm{H}_{5 \text {-quin }}\right), 6.56(\mathrm{~s}, 2 \mathrm{H},=\mathrm{CHN}), 6.06(\mathrm{~d}$, $\left.J_{\mathrm{H}-\mathrm{H}}=8.3,1 \mathrm{H}, \mathrm{H}_{3 \text {-quin }}\right), 3.48\left(\mathrm{br}, 4 \mathrm{H}, \mathrm{CHMe}_{\mathrm{IPr}}\right), 2.75$ and 2.10 (both d, $J_{\mathrm{H}-\mathrm{H}}=10.4,4 \mathrm{H}, \mathrm{CH}_{2}=\mathrm{CH}_{2}$ ), $1.76\left(\mathrm{~s}, 3 \mathrm{H}, \mathrm{Me}_{\text {quin }}\right.$ ), 1.55 and 1.12 (both $\mathrm{d}, J_{\mathrm{H}-\mathrm{H}}=6.7,24 \mathrm{H}, \mathrm{CHM} \underline{\mathrm{M}}_{\mid \mathrm{Pr}}$ ). ${ }^{13} \mathrm{C}\left\{{ }^{1} \mathrm{H}\right\}-\mathrm{APT}$ NMR $\left(100.6 \mathrm{MHz}, \mathrm{C}_{6} \mathrm{D}_{6}, 298 \mathrm{~K}\right): \delta 183.9\left(\mathrm{~d}, J_{\mathrm{C}-\mathrm{Rh}}=59.3, \mathrm{Rh}-\mathrm{C}_{\mathrm{IPr}}\right)$, 171.0 (s, $\left.C_{8 \text {-quin }}\right), 157.7$ (s, $\left.C_{\text {2-quin }}\right), 146.6\left(\mathrm{~s}, \mathrm{C}_{\mathrm{q}-\mathrm{IPr}}\right), 144.4$ (s, $\mathrm{C}_{8 \mathrm{a}-}$ quin), $136.3\left(\mathrm{~s}, \mathrm{C}_{4-\text { quin }}\right), 137.0\left(\mathrm{~s}, \mathrm{C}_{\mathrm{q}} \mathrm{N}\right), 129.6\left(\mathrm{~s}, \mathrm{CH}_{\mathrm{Ph}-\mathrm{Pr}}\right), 128.6$ (s, $\left.\mathrm{C}_{4 a-q u i n}\right), 128.6\left(\mathrm{~s}, \mathrm{C}_{6 \text {-quin }}\right), 124.8(\mathrm{~s},=\mathrm{CHN}), 123.1$ (s, $\left.\mathrm{C}_{3 \text {-quin }}\right)$, 113.9 (s, $C_{5-\text { quin }}$ ), 109.4 (s, $\left.C_{7-\text { quin }}\right), 38.3$ (d, $J_{C-R h}=15.4$, $\mathrm{CH}_{2}=\mathrm{CH}_{2}$ ), $28.8\left(\mathrm{~s}, \underline{\mathrm{C}} \mathrm{HMe}_{\mathrm{IPr}}\right.$ ), 26.2 and 23.3 (both s, $\mathrm{CHMe} \underline{\mathrm{Pr}}_{\mathrm{Pr}}$ ), 22.1 ( $\left.\mathrm{Me}_{\text {quin }}\right)$.

In situ formation of $\mathrm{RhH}\left\{\kappa^{2}-\mathrm{O}, \mathrm{N}-\left(\mathrm{C}_{9} \mathrm{H}_{6} \mathrm{NO}\right)\right\}(\mathrm{SPh})(\mathrm{IPr})$ (9). A toluene- $d_{8}$ solution of $5(25 \mathrm{mg}, 0.033 \mathrm{mmol})$ in an NMR tube at $298 \mathrm{~K}$ was treated with thiophenol $(5 \mu \mathrm{l}, 0.049 \mathrm{mmol})$. NMR spectra were recorded after $1 \mathrm{~h}$ at $298 \mathrm{~K}$. HRMS (ESI) $\mathrm{m} / \mathrm{z}$ calcd for $\mathrm{RhC}_{42} \mathrm{H}_{47} \mathrm{~N}_{3} \mathrm{OS}(\mathrm{M}-\mathrm{H})^{+} 744.2489$ found 744.2473. ${ }^{1} \mathrm{H}$ NMR $\left(500 \mathrm{MHz}\right.$, toluene- $\left.d_{8}, 298 \mathrm{~K}\right): \delta 8.58\left(\mathrm{~d}, J_{\mathrm{H}-}\right.$ $\left.{ }_{H}=4.6,1 \mathrm{H}, \mathrm{H}_{2 \text {-quin }}\right), 7.27\left(\mathrm{dd}, J_{\mathrm{H}-\mathrm{H}}=8.0,7.9,1 \mathrm{H}, \mathrm{H}_{6 \text {-quin }}\right), 7.13$ $\left(\mathrm{d}, J_{\mathrm{H}-\mathrm{H}}=8.2,1 \mathrm{H}, \mathrm{H}_{4 \text {-quin }}\right), 7.06\left(\mathrm{~d}, J_{\mathrm{H}-\mathrm{H}}=8.0,1 \mathrm{H}, \mathrm{H}_{7 \text {-quin }}\right), 7.1-6.7$ $\left(\mathrm{m}, 11 \mathrm{H}, \mathrm{H}_{\mathrm{Ph}}\right), 6.74(\mathrm{~s}, 2 \mathrm{H},=\mathrm{CHN}), 6.51\left(\mathrm{~d}, J_{\mathrm{H}-\mathrm{H}}=7.9,1 \mathrm{H}, \mathrm{H}_{5-}\right.$ quin), 6.14 (dd, $J_{\mathrm{H}-\mathrm{H}}=8.2,4.6,1 \mathrm{H}, \mathrm{H}_{3 \text {-quin }}$ ), 3.52 (sept, $J_{\mathrm{H}-\mathrm{H}}=6.5$, $1 \mathrm{H}, \mathrm{CHMe}_{\mathrm{Ipr}}$ ), 3.40 (sept, $J_{\mathrm{H}-\mathrm{H}}=6.5,2 \mathrm{H}, \mathrm{CH}^{\mathrm{H}} \mathrm{Me}_{\mathrm{Ipr}}$ ), 2.03 (br, $1 \mathrm{H}$, CHMe ${ }_{\text {Ipr }}$ ), 1.49, 1.41, 1.40, 1.37, 1.35, 1.16, 1.13, and 1.12 (all $\left.\mathrm{d}, J_{\mathrm{H}-\mathrm{H}}=6.5,24 \mathrm{H}, \mathrm{CHMe} \underline{\mathrm{pr}}_{\mathrm{pr}}\right),-26.74\left(\mathrm{~d}, J_{\mathrm{H}-\mathrm{Rh}}=50.1,1 \mathrm{H}, \mathrm{Rh}-\mathrm{H}\right)$. ${ }^{13} \mathrm{C}\left\{{ }^{1} \mathrm{H}\right\}$-APT NMR $\left(125.6 \mathrm{MHz}\right.$, toluene- $\left.d_{8}, 298 \mathrm{~K}\right): \delta 184.1(\mathrm{~d}$, $\left.J_{C-R h}=50.7, R h-C_{1 P r}\right), 175.4\left(s, C_{8-q u i n}\right), 155.8\left(s, C_{q} S\right), 152.4$ and 152.3 (both $\mathrm{s}, \mathrm{C}_{\mathrm{q}-\mathrm{IPr}}$ ), 152.2 (s, $\left.\mathrm{C}_{\text {2-quin }}\right), 150.1$ (s, $\mathrm{C}_{\text {8a-quin }}$ ), 142.3 (s, $\mathrm{C}_{\mathrm{q}} \mathrm{N}$ ), 141.5 (s, $\left.\mathrm{C}_{4 \text {-quin }}\right), 136.6$ (s, $\left.\mathrm{C}_{\text {o-sph }}\right), 135.6$ (s, $\left.\mathrm{C}_{4 \mathrm{a} \text {-quin }}\right)$, 135.1 (s, $\mathrm{C}_{6 \text {-quin }}$ ), 132.4, 128.8, and 125.8 (all s, $\mathrm{CH}_{\mathrm{Ph}}$ ), 129.6 (s, $\left.\mathrm{C}_{m \text {-Sph }}\right), 129.3$ (s, =CHN), 125.7 (s, $\left.\mathrm{C}_{p \text {-sph }}\right), 125.2$ (s, $\left.\mathrm{C}_{3 \text {-quin }}\right)$, 119.2 (s, $\mathrm{C}_{7 \text {-quin }}$ ), 115.2 (s, $\mathrm{C}_{5 \text {-quin }}$ ), 34.1 and 33.9 (both $\mathrm{s}$, $\underline{\mathrm{CHMe}}_{\mathrm{IPr}}$ ), 31.5, 31.2, 28.0, and 27.7 (all s, $\mathrm{CHMe} \underline{\mathrm{IPr}}_{\mathrm{Pr}}$ ).

In situ formation of $\mathrm{RhH}\left\{\kappa^{2}-\mathrm{O}, \mathrm{N}-\left(\mathrm{C}_{9} \mathrm{H}_{6} \mathrm{NO}\right)\right\}(\mathrm{SPh})(\mathrm{IPr})(\mathrm{py})$ (10). A freshly prepared toluene- $d_{8}$ solution of 9 in an NMR tube starting from $5(25 \mathrm{mg}, 0.033 \mathrm{mmol})$ and thiophenol (5 $\mu \mathrm{L}, 0.049 \mathrm{mmol})$, was treated with pyridine $(9 \mu \mathrm{L}, 0.11 \mathrm{mmol})$ at $213 \mathrm{~K}$. NMR spectra were recorded immediately. ${ }^{1} \mathrm{H}$ NMR (500 MHz, toluene- $d_{8}, 213 \mathrm{~K}$ ): $\delta 9.59$ and 7.52 (both br, $2 \mathrm{H}$, $\left.\mathrm{H}_{2-\text { py }}\right), 8.14\left(\mathrm{~d}, J_{\mathrm{H}-\mathrm{H}}=4.2,1 \mathrm{H}, \mathrm{H}_{2 \text {-quin }}\right), 7.34\left(\mathrm{br}, 2 \mathrm{H}, \mathrm{H}_{o-\mathrm{Sph}}\right), 7.03$ (dd, $\left.J_{\mathrm{H}-\mathrm{H}}=8.1,7.8,1 \mathrm{H}, \mathrm{H}_{6 \text {-quin }}\right), 6.92\left(\mathrm{~d}, J_{\mathrm{H}-\mathrm{H}}=8.1,1 \mathrm{H}, \mathrm{H}_{7 \text {-quin }}\right)$, 7.0-6.0 (m, $\left.12 \mathrm{H}, \mathrm{H}_{\mathrm{Ph}-\mathrm{IPr}}, \mathrm{H}_{\mathrm{Ph}-\mathrm{SPh}}, \mathrm{H}_{4-q u i n}\right), 6.38$ and 6.17 (both $\mathrm{s}$, $2 \mathrm{H},=\mathrm{CHN}), 6.37\left(\mathrm{dd}, J_{\mathrm{H}-\mathrm{H}}=7.6,7.3,1 \mathrm{H}, \mathrm{H}_{6-\mathrm{py}}\right), 6.10\left(\mathrm{~d}, J_{\mathrm{H}-\mathrm{H}}=\right.$ $7.8,1 \mathrm{H}, \mathrm{H}_{5-\text { quin }}$ ), 5.92 and 5.41 (both $\mathrm{m}, 2 \mathrm{H}, \mathrm{H}_{3-\mathrm{py}}, \mathrm{H}_{5-\mathrm{py}}$ ), 5.64 (dd, $\left.J_{\mathrm{H}-\mathrm{H}}=8.1,4.2,1 \mathrm{H}, \mathrm{H}_{3 \text {-quin }}\right), 3.4-3.0\left(\mathrm{br}, 4 \mathrm{H}, \mathrm{CHMe}_{\text {|pr }}\right.$ ), 1.60.7 (br, 24H, CHMe $\mathrm{Ipr}_{\mathrm{pr}}$ ), $-16.02\left(\mathrm{~d}, \mathrm{~J}_{\mathrm{H}-\mathrm{Rh}}=19.7,1 \mathrm{H}, \mathrm{Rh}-\mathrm{H}\right)$. ${ }^{13} \mathrm{C}\left\{{ }^{1} \mathrm{H}\right\}-$ APT NMR $\left(125.6 \mathrm{MHz}\right.$, toluene- $\left.d_{8}, 213 \mathrm{~K}\right): \delta 177.1(\mathrm{~d}$, $\left.J_{\mathrm{C}-\mathrm{Rh}}=53.6, \mathrm{Rh}-\mathrm{C}_{\mathrm{IPr}}\right), 171.1\left(\mathrm{~s}, \mathrm{C}_{8-\text { quin }}\right), 150.0\left(\mathrm{br}, \mathrm{C}_{2-\mathrm{py}}\right), 147.3$, 147.0, 146.5, and 146.3 (all s, $C_{\text {q-IPr }}$ ), 145.6 (s, $C_{2 \text {-quin }}$ ), 144.7 (s, $\mathrm{C}_{8 \mathrm{a} \text {-quin }}$ ), 137.3 and 137.1 (both $\left.\mathrm{s}, \mathrm{C}_{\mathrm{q}} \mathrm{N}\right), 137-125\left(\mathrm{~s}, \mathrm{C}_{\mathrm{Ph}}\right), 135.5$ (s, $\left.C_{\text {4-quin }}\right), 134.7$ (s, $\left.C_{4-p y}\right), 130.5$ (s, $\left.C_{4 a-q u i n}\right), 130.2$ (s, $C_{6-q u i n}$ ), 125.0 (s, =CHN), 122.4 y 121.9 (ambos s, $\left.C_{3-p y}, C_{5-p y}\right), 120.4$ (s, $\mathrm{C}_{3 \text {-quin }}$ ), 113.9 (s, $\mathrm{C}_{7 \text {-quin }}$ ), 108.2 (s, $\mathrm{C}_{5 \text {-quin }}$ ), 29-21 ( $\mathrm{CHMe}_{\mathrm{IPr}}$ ).

In situ formation of $\mathrm{Rh}\left(\eta^{1}-\mathrm{CH}_{2} \mathrm{CH}_{3}\right)\left\{\kappa^{2}-\mathrm{O}, \mathrm{N}-\right.$ $\left.\left(\mathrm{C}_{9} \mathrm{H}_{6} \mathrm{NO}\right)\right\}(\mathrm{SPh})(\mathrm{IPr})$ (11). A toluene- $d_{8}$ solution of $6(33 \mathrm{mg}$, $0.050 \mathrm{mmol}$ ) in a NMR tube was treated with thiophenol (6 $\mu \mathrm{L}, 0.060 \mathrm{mmol})$ and pyridine $(15 \mu \mathrm{L}, 0.18 \mathrm{mmol})$. After 15 min at room temperature, NMR spectra were recorded at low temperature. ${ }^{1} \mathrm{H}$ NMR (400 MHz, toluene- $d_{8}, 223 \mathrm{~K}$ ): $\delta$ $8.62\left(\mathrm{~d}, J_{\mathrm{H}-\mathrm{H}}=5.0,1 \mathrm{H}, \mathrm{H}_{2-\text { quin }}\right), 7.47\left(\mathrm{dd}, J_{\mathrm{H}-\mathrm{H}}=7.6,7.5,1 \mathrm{H}, \mathrm{H}_{6-}\right.$ quin), $7.30\left(\mathrm{~d}, J_{\mathrm{H}-\mathrm{H}}=7.6,1 \mathrm{H}, \mathrm{H}_{7 \text {-quin }}\right), 7.3-6.7\left(\mathrm{~m}, 14 \mathrm{H}, \mathrm{H}_{\mathrm{Ph}-\mathrm{Pr}}\right.$, $\left.\mathrm{H}_{\text {Ph-SPh, }} \mathrm{H}_{4-\text { quin, }}=\mathrm{CHN}\right), 6.64\left(\mathrm{~d}, J_{\mathrm{H}-\mathrm{H}}=7.5,1 \mathrm{H}, \mathrm{H}_{5 \text {-quin }}\right), 6.17$ (dd, $\left.J_{\mathrm{H}-\mathrm{H}}=8.2,5.0,1 \mathrm{H}, \mathrm{H}_{3 \text {-quin }}\right), 3.7-3.5\left(\mathrm{~m}, 4 \mathrm{H}, \mathrm{CHMe}_{\mathrm{Ipr}}\right), 3.20$ and

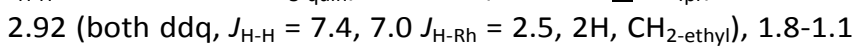
$\left(24 \mathrm{H}, \mathrm{CHMe}{ }_{1 p r}\right),-0.36$ (dvt, $\left.J_{\mathrm{H}-\mathrm{Rh}}=1.0, \mathrm{~N}=14.0,2 \mathrm{H}, \mathrm{CH}_{3 \text {-ethyl }}\right)$. ${ }^{13} \mathrm{C}\left\{{ }^{1} \mathrm{H}\right\}$-APT NMR $\left(100.6 \mathrm{MHz}\right.$, toluene- $\left.d_{8}, 223 \mathrm{~K}\right): \delta 174.0(\mathrm{~d}$, $\left.J_{C-R h}=53.2, R h-C_{1 P r}\right), 170.5\left(s, C_{8-q u i n}\right), 151.2\left(s, C_{q} S\right), 148.2(s$, $\mathrm{C}_{\text {2-quin }}$ ), 147.0, 146.6, 146.1, and 145.8 (all s, $\mathrm{C}_{\text {q-IPr }}$ ), 144.7 (s, $\mathrm{C}_{8 \mathrm{a} \text {-quin }}$ ), 137.3 and 136.0 (both $\mathrm{s}, \mathrm{C}_{\mathrm{q}} \mathrm{N}$ ), 136.8 (s, $\mathrm{C}_{4 \text {-quin }}$ ), 130.5 (s, $\left.\mathrm{C}_{4 \mathrm{a} \text {-quin }}\right), 129.8\left(\mathrm{~s}, \mathrm{C}_{6-\text { quin }}\right), 129-123\left(\mathrm{CH}_{\mathrm{Ph}},=\mathrm{CHN}\right), 121.3$ (s, $\left.\mathrm{C}_{\text {3-quin }}\right), 114.8\left(\mathrm{~s}, \mathrm{C}_{7 \text {-quin }}\right), 110.3\left(\mathrm{~s}, \mathrm{C}_{5 \text {-quin }}\right), 29-23\left(\mathrm{CHMe}_{\mathrm{IPr}}\right)$, 20.4 (d, $\left.J_{\mathrm{C}-\mathrm{Rh}}=27.1, \mathrm{CH}_{\text {2-ethyl }}\right), 18.7$ (s, $\mathrm{CH}_{3 \text {-ethyl }}$ ).

In situ formation of $\mathrm{Rh}\left(\eta^{1}-\mathrm{C}(\mathrm{Ph})=\mathrm{CH}_{2}\right)\left\{x^{2}-\mathrm{O}, \mathrm{N}-\right.$ $\left.\left(\mathrm{C}_{9} \mathrm{H}_{6} \mathrm{NO}\right)\right\}(\mathrm{SPh})(\mathrm{IPr})$ (12) and $\mathrm{Rh}\left(\eta^{1}-\mathrm{CH}=\mathrm{CHPh}\right)\left\{\kappa^{2}-\mathrm{O}, \mathrm{N}-\right.$ $\left.\left(\mathrm{C}_{9} \mathrm{H}_{6} \mathrm{NO}\right)\right\}(\mathrm{SPh})(\mathrm{IPr})$ (13). A freshly prepared toluene- $d_{8}$ solution of 9 in an NMR tube starting from 5 (25 mg, 0.033 $\mathrm{mmol}$ ) and thiophenol $(5 \mu \mathrm{L}, 0.049 \mathrm{mmol})$, was treated with phenylacetylene $(5 \mu \mathrm{L}, 0.045 \mathrm{mmol})$. After $1 \mathrm{~h}$ at room temperature the spectra were recorded at low temperature. A mixture of 12:13 in 56:44 ratio was obtained. HRMS (ESI) $\mathrm{m} / \mathrm{z}$ calcd for $\mathrm{RhC}_{50} \mathrm{H}_{53} \mathrm{~N}_{3} \mathrm{OS}(\mathrm{M}-\mathrm{H})^{+} 846.2959$ found 846.2943. 12: ${ }^{1} \mathrm{H}$ NMR (500 MHz, toluene- $d_{8}, 243 \mathrm{~K}$ ): $\delta 8.86$ (d, $\left.J_{H-H}=4.7,1 \mathrm{H}, \mathrm{H}_{2 \text {-quin }}\right), 7.23\left(\mathrm{dd}, J_{\mathrm{H}-\mathrm{H}}=7.7,7.6,1 \mathrm{H}, \mathrm{H}_{6 \text {-quin }}\right)$, $7.19\left(\mathrm{~d}, J_{\mathrm{H}-\mathrm{H}}=7.7,1 \mathrm{H}, \mathrm{H}_{7 \text {-quin }}\right), 6.69\left(\mathrm{~d}, J_{\mathrm{H}-\mathrm{H}}=8.1,1 \mathrm{H}, \mathrm{H}_{4 \text {-quin }}\right)$, 7.1-6.2 (16H, $\left.\mathrm{H}_{\mathrm{Ph}}\right), 6.70(\mathrm{~s}, 2 \mathrm{H},=\mathrm{CHN}), 6.43\left(\mathrm{~d}, J_{\mathrm{H}-\mathrm{H}}=7.6,1 \mathrm{H}\right.$, $\left.\mathrm{H}_{5 \text {-quin }}\right), 6.12\left(\mathrm{dd}, J_{\mathrm{H}-\mathrm{H}}=8.1,4.7,1 \mathrm{H}, \mathrm{H}_{3 \text {-quin }}\right), 4.77$ and 4.73 (both br, $2 \mathrm{H},=\mathrm{CH}_{2}$ ), 3.55 and 3.43 (both sept, $J_{\mathrm{H}-\mathrm{H}}=6.5,4 \mathrm{H}$, $\mathrm{CH} \mathrm{He}_{\mathrm{Ipr}}$ ), 1.85, 1.18, 1.11, and 1.03 (all d, $J_{\mathrm{H}-\mathrm{H}}=6.5,24 \mathrm{H}$, CHMe $\left.{ }_{1 p r}\right) .{ }^{13} \mathrm{C}\left\{{ }^{1} \mathrm{H}\right\}$-APT NMR (125.6 MHz, toluene- $\left.d_{8}, 243\right): \delta$ $174.5\left(\mathrm{~d}, J_{\mathrm{C}-\mathrm{Rh}}=54.3, \mathrm{Rh}-\mathrm{C}_{\mathrm{IPr}}\right), 170.4\left(\mathrm{~s}, \mathrm{C}_{8 \text {-quin }}\right), 151.0\left(\mathrm{~s}, \mathrm{C}_{\mathrm{q}} \mathrm{S}\right)$, 148.8 (s, $\mathrm{C}_{\text {2-quin }}$ ), 147.5 and 145.6 (both $\mathrm{s}, \mathrm{C}_{\mathrm{q}-\mathrm{IPr}}$ ), 145.7 (s, $\mathrm{C}_{\mathrm{q}-}$ Ph), 145.1 (s, $\left.\mathrm{C}_{8 \mathrm{a} \text {-quin }}\right), 143.4\left(\mathrm{~d}, \mathrm{~J}_{\mathrm{C}-\mathrm{Rh}}=37.8, \underline{\mathrm{CPh}}=\mathrm{CH}_{2}\right), 143.0(\mathrm{~s}$, $\mathrm{C}_{\mathrm{q}} \mathrm{N}$ ), 136.9 (s, $\mathrm{C}_{4-\text { quin }}$ ), 131.0 (s, $\mathrm{C}_{4 \mathrm{a}-\text { quin }}$ ), 130-120 ( $\left.\mathrm{C}_{\mathrm{Ph}}\right), 129.6$ (s, $\mathrm{C}_{6 \text {-quin }}$ ), 123.6 (br, $\mathrm{CPh}=\underline{\mathrm{CH}}_{2}$ ), 120.8 (s, $\mathrm{C}_{3 \text {-quin }}$ ), 120.4 (s, $=\mathrm{CHN}$ ), 116.1 (s, $\mathrm{C}_{7 \text {-quin }}$ ), 112.0 (s, $\mathrm{C}_{5 \text {-quin }}$ ), 30.2 and 30.0 (both s, $\left.\underline{\mathrm{C}} \mathrm{HMe}_{\mathrm{IPr}}\right), 27.9,27.4,23.3$, and 23.0 (CHMe $\left.\underline{\mathrm{CPr}}_{\mathrm{IP}}\right) .13:{ }^{1} \mathrm{H} \mathrm{NMR}$ (500 MHz, toluene- $d_{8}, 243 \mathrm{~K}$ ): $\delta 8.64\left(\mathrm{~d}, J_{\mathrm{H}-\mathrm{H}}=4.8,1 \mathrm{H}, \mathrm{H}_{2 \text {-quin }}\right)$, $7.41\left(\mathrm{dd}, J_{\mathrm{H}-\mathrm{H}}=8.1,7.3,1 \mathrm{H}, \mathrm{H}_{6 \text {-quin }}\right), 7.33\left(\mathrm{~d}, J_{\mathrm{H}-\mathrm{H}}=8.1,1 \mathrm{H}, \mathrm{H}_{7-}\right.$ quin), $7.02\left(\mathrm{~d}, J_{\mathrm{H}-\mathrm{H}}=8.2,1 \mathrm{H}, \mathrm{H}_{4-\text { quin }}\right), 7.2-6.2\left(17 \mathrm{H}, \mathrm{H}_{\mathrm{Ph}}\right.$, $\mathrm{C} \underline{\mathrm{H}}=\mathrm{CHPh}), 6.55\left(\mathrm{~d}, J_{\mathrm{H}-\mathrm{H}}=7.3,1 \mathrm{H}, \mathrm{H}_{5-\text { quin }}\right), 6.05\left(\mathrm{dd}, J_{\mathrm{H}-\mathrm{H}}=8.2\right.$, $4.8,1 \mathrm{H}, \mathrm{H}_{3 \text {-quin }}$ ), 5.84 (dd, $J_{\mathrm{H}-\mathrm{H}}=12.5,1.9,1 \mathrm{H}, \mathrm{CH}=\mathrm{C} \underline{\mathrm{HPh}}$ ), 3.53.3 and 1.9-0.9 $\left(28 \mathrm{H}, \mathrm{CHMe}_{\mathrm{Ipr}}\right), 1.85,1.18,1.11$, and 1.03 (all d, $\left.J_{\mathrm{H}-\mathrm{H}}=6.5,12 \mathrm{H}, \mathrm{CHMe} / \mathrm{pr}\right) .{ }^{13} \mathrm{C}\left\{{ }^{1} \mathrm{H}\right\}-\mathrm{APT}$ NMR $(125.6 \mathrm{MHz}$, toluene- $\left.d_{8}, 234 \mathrm{~K}\right): \delta 172.3\left(\mathrm{~d}, \mathrm{~J}_{\mathrm{C}-\mathrm{Rh}}=51.5, \mathrm{Rh}-\mathrm{C}_{\mathrm{IPr}}\right), 170.3(\mathrm{~s}$, $\mathrm{C}_{\text {8-quin }}$ ), $150.9\left(\mathrm{~s}, \mathrm{C}_{\mathrm{q}} \mathrm{S}\right), 148.1$ ( $\left.\mathrm{s}, \mathrm{C}_{\text {2-quin }}\right), 144.7$ (s, $\left.\mathrm{C}_{\text {8a-quin }}\right), 136.8$ (s, $\left.\mathrm{C}_{4-\text { quin }}\right), 131-120\left(\mathrm{~s}, \mathrm{C}_{\mathrm{Ph}}\right), 130.5\left(\mathrm{~s}, \mathrm{C}_{4 \mathrm{a} \text {-quin }}\right), 130.0$ (s, $\left.\mathrm{C}_{6 \text {-quin }}\right)$, $131.2(\mathrm{~s}, \mathrm{CH}=\underline{\mathrm{CHPh}}), 130-120\left(\mathrm{C}_{\mathrm{Ph}}\right), 126.2\left(\mathrm{~d}, J_{\mathrm{C}-\mathrm{Rh}}=39.4\right.$, $\underline{\mathrm{C}} \mathrm{H}=\mathrm{CHPh}$ ), 120.4 (s, $\left.\mathrm{C}_{3 \text {-quin }}\right), 115.8$ (s, $\left.\mathrm{C}_{7 \text {-quin }}\right), 111.8$ (s, $\left.\mathrm{C}_{5 \text {-quin }}\right)$, 29-23 (CHMe IPr).

In situ formation of $\mathrm{Rh}\left(\eta^{1}-\mathrm{CH}=\mathrm{CHPh}\right)\left\{\kappa^{2}-\mathrm{O}, \mathrm{N}-\right.$ $\left.\left(\mathrm{C}_{9} \mathrm{H}_{6} \mathrm{NO}\right)\right\}(\mathrm{SPh})(\mathrm{IPr})(\mathrm{py})$ (14). A freshly prepared toluene- $d_{8}$ solution of 12 and 13 in an NMR tube was treated with pyridine ( $9 \mu \mathrm{L}, 0.11 \mathrm{mmol})$. A mixture of 12:13:14 in 54:31:15 ratio was obtained. 14: ${ }^{1} \mathrm{H}$ RMN (300 MHz, tol- $d_{8}, 243 \mathrm{~K}$ ): $\delta$ $8.90\left(\mathrm{~d}, J_{\mathrm{H}-\mathrm{H}}=5.2,2 \mathrm{H}, \mathrm{H}_{2-\mathrm{py}}\right), 8.76\left(\mathrm{~d}, J_{\mathrm{H}-\mathrm{H}}=15.8,1 \mathrm{H}\right.$, 
$\mathrm{C} \underline{\mathrm{H}}=\mathrm{CHPh}), 8.62\left(\mathrm{~d}, J_{\mathrm{H}-\mathrm{H}}=4.5,1 \mathrm{H}, \mathrm{H}_{2 \text {-quin }}\right), 7.39\left(\mathrm{~d}, J_{\mathrm{H}-\mathrm{H}}=15.8\right.$, $1 \mathrm{H}, \mathrm{CH}=\mathrm{C}$ P Ph), 5.80 (dd, $\left.J_{\mathrm{H}-\mathrm{H}}=5.2,5.4,2 \mathrm{H}, \mathrm{H}_{3-\mathrm{py}}\right)$.

Catalytic hydrothiolation of phenylacetylene. A NMR tube containing a solution of $0.01 \mathrm{mmol}$ of catalyst in $0.5 \mathrm{~mL}$ of $\mathrm{C}_{6} \mathrm{D}_{6}$ was treated with $0.5 \mathrm{mmol}$ of thiophenol and $0.5 \mathrm{mmol}$ of phenylacetylene. The reaction was monitored by ${ }^{1} \mathrm{H}$ NMR at $25 \circ \mathrm{C}$ and the conversion was determined by integration of the corresponding resonances of the alkyne and the products. The final reaction products was analysed by GC-MS analysis.

Crystal Structure Determination for complexes $5 b, 7$ and 8. Single crystals for the $\mathrm{X}$-ray diffraction studies were grown by slow diffusion of $n$-hexane into toluene ( $5 \mathbf{b}$ and $\mathbf{7}$ ) or benzene (8) solutions of the complexes. X-ray diffraction data were collected at $100(2) \mathrm{K}$ on a Bruker SMART APEX (5b and 8) or APEX DUO (7) CCD diffractometers with graphitemonochromated Mo-K $\alpha$ radiation $(\lambda=0.71073 \AA$ ) using narrow $\omega$ rotations $\left(0.3^{\circ}\right)$. Intensities were integrated and corrected for absorption effects with SAINT-PLUS, ${ }^{38}$ and $\mathrm{SADABS}^{39}$ programs, both included in APEX2 package. The structures were solved by Patterson methods with SHELXS$97^{40}$ and refined, by full matrix least-squares on $F^{2}$, with SHELXL-97. ${ }^{41}$ Both structures were refined first with isotropic and later with anisotropic displacement parameters for nondisordered non-H atoms. Specific relevant details on each structure are described below. CCDC 1485401-1485403 contain the supplementary crystallographic data for this paper. These data can be obtained free of charge from The Cambridge Crystallographic Data Centre via www.ccdc.cam.ac.uk/data request/cif.

Crystal data for 5b: $\mathrm{C}_{44} \mathrm{H}_{56} \mathrm{~N}_{3} \mathrm{ORh} ; M=745.82$; red block $0.254 \times 0.164 \times 0.130 \mathrm{~mm}^{3} ;$ monoclinic, $P 2_{1} / \mathrm{n} ; a=$ 11.4926(16), $b=17.417(2), c=19.109$ (3) $\AA, \quad b=103.684(2)^{\circ} ; Z$ $=4 ; V=3716.5(9) \AA^{3} ; D_{\mathrm{c}}=1.333 \mathrm{~g} \cdot \mathrm{cm}^{-3} ; \mu=0.497 \mathrm{~mm}^{-1} ; \min$. and max. absorption correction factors 0.407 and 0.528 ; $2 \theta_{\max }=56.82^{\circ} ; 42370$ reflections collected, 8738 unique $\left(R_{\mathrm{int}}\right.$ $=0.0801) ;$ number of data/restraints $/$ parameters 8738/0/649; final GOF 1.077; $R_{1}=0.0618$ (6104 reflections, I $>2 \sigma(I)) ; \mathrm{W} R\left(F^{2}\right)=0.1242$ for all data. Most of the hydrogen atoms were observed in the difference Fourier maps and refined as free independent isotropic atoms. Some of them $(H(2), H(3), H(10), H(13), H(25)$ and $H(34)$, and those bonded to terminal methyl groups $C(11), C(12), C(14)$ and $C(27)$ ) have required a riding displacement parameters to get sensible values.

Crystal data for 7: $\mathrm{C}_{45} \mathrm{H}_{58} \mathrm{~N}_{3} \mathrm{ORh} ; M=759.85$; red block 0.186 $\times 0.181 \times 0.134 \mathrm{~mm}^{3}$; triclinic, $P 2_{1} / n ; a=11.3475(14), b=$ 127.783(2), $c=19.583(2) \AA, \quad b=103.994(2)^{\circ} ; Z=4 ; V=$ 3834.4(8) $\AA^{3} ; D_{c}=1.316 \mathrm{~g} \cdot \mathrm{cm}^{-3} ; \mu=0.484 \mathrm{~mm}^{-1} ; \min$. and max. absorption correction factors 0.792 and $0.914 ; 2 \theta_{\max }=$ $59.00^{\circ} ; 40863$ reflections collected, 9929 unique $\left(R_{\mathrm{int}}=\right.$ 0.0338 ); number of data/restraints/parameters $9929 / 6 / 676$; final GOF 1.029; $R_{1}=0.0323$ (8011 reflections, $I>2 \sigma(I)$ ); $\mathrm{W} R\left(F^{2}\right)=0.0822$ for all data. A static disorder was observed for two carbon atoms of the cyclooctene (C42 and C43); they were included in two equivalent positions with bond distance restrictions for all $\mathrm{C}-\mathrm{C}$ distances involving these disordered atoms. Hydrogen atoms were observed from difference Fourier maps and refined as free isotropic atoms.

Crystal data for 8: $\mathrm{C}_{39} \mathrm{H}_{48} \mathrm{~N}_{3} \mathrm{ORh} \cdot 4 \mathrm{C}_{6} \mathrm{H}_{6} ; M=990.14$; orange prism $0.374 \times 0.182 \times 0.122 \mathrm{~mm}^{3}$; monoclinic; $P 2_{1} / n ; a=$ 11.4003(6), $b=29.8414(15), \quad c=16.2873(8) \AA, \quad b=$ $105.5120(10)^{\circ} ; Z=4 ; V=5339.1(5) \AA^{3} ; D_{c}=1.232 \mathrm{~g} \cdot \mathrm{cm}^{-3} ; \mu=$ $0.363 \mathrm{~mm}^{-1} ; \mathrm{min}$. and max. absorption correction factors 0.833 and $0.941 ; 2 \theta_{\max }=57.33^{\circ} ; 111158$ reflections collected, 13095 unique $\left(R_{\text {int }}=0.0399\right) ;$ number of data/restraints/parameters 13095/0/892; final GOF 1.053; $R_{1}$ $=0.0327(11604$ reflections, $I>2 \sigma(I)) ; \mathrm{w} R\left(F^{2}\right)=0.0807$ for all data. Hydrogens of the metal complex were included from observed positions and refined as free isotropic atoms. Four clear benzene solvent molecules were observed in the crystal structure; their hydrogen atoms were also included in the structure, although some of them with riding parameters.

Computational details. All DFT theoretical calculations have been carried out using the Gaussian program package. ${ }^{42}$ The B3LYP method ${ }^{43}$ has been employed, including the D3 dispersion correction scheme developed by Grimme ${ }^{45}$ for both energies and gradient calculations and the "ultrafine" grid. The def2-SVP basis set ${ }^{45}$ has been selected for all atoms. The nature of the stationary points has been confirmed by analytical frequency analysis. In the Table XX (see supporting information) we have reported the computational results including the cartesian coordinates (in $\AA$ ), absolute energy (in a.u) and graphical representation.

\section{Acknowledgements}

Financial support from the Spanish Ministerio de Economía y Competitividad (MEC/FEDER) of Spain (Project CTQ201342532-P), the Diputación General de Aragón (E07) and CONSOLIDER INGENIO-2010, under the Project MULTICAT (CSD2009-00050) are gratefully acknowledged. The support under the KFUPM-University of Zaragoza research agreement is also highly appreciated. ADG thanks the "Subprograma de Formación Posdoctoral" from the Ministerio de Economia y Competitividad.

\section{Notes and references}

1 (a) P. Bichler, J. Love in Topics of Organometallic Chemistry, Vol. 31 (Ed.: A. Vigalok), Springer, Heidelberg, 2010, pp. 36-64; (b) I. P. Beletskaya, V. P. Ananikov, Chem. Rev., 2011, 111, 1596; (c) R. Castarlenas, A. Di Giuseppe, J. J. Pérez-Torrente, L. A. Oro, Angew. Chem. Int. Ed., 2013, 52, 211; (d) A. Ogawa, in Topics of Organometallic Chemistry, Vol. 43 (Eds.: V. P. Ananikov, M. Tanaka), Springer, Heidelberg, 2013, pp. 325-360; (e) A. Dondoni, A Marra, Eur. J. Org. Chem., 2014, 3955; f) N. V. Orlov, ChemistryOpen, 2015, 4, 682.

2 (a) K. Griesbaum, Angew. Chem. Int. Ed., 1970, 9, 273; (b) L. Benati, L. Capella, P. C. Montevecchi, P. Spagnolo J. Org. Chem., 1994, 59, 2818; (c) M. Lo Conte, S. Pacifico, A Chambery, A. Marra, A. Dondoni, J. Org. Chem., 2010, 75, 4644.

3 (a) V. N. Ipatieff, H. Pines, B. S. Friedman, J. Am. Chem. Soc., 1938, 60, 2731; (b) C. G. Screttas, M. Micha-Screttas, J. Org. 
Chem., 1979, 44, 713; (c) M. Weïwer, L. Coulombel, E. Duñach, Chem. Commun., 2006, 332.

4 (a) W. E. Truce, J. A. Simms, M. M. Boudakian, J. Am. Chem. Soc., 1956, 78, 695; (b) A. Kondoh, K. Takami, H. Yorimitsu, K. Oshima, J. Org. Chem., 2005, 70, 6468, (c) R. Kumar, Saima, A. Shard, N. H. Andhare, Richa, A. K. Sinha, Angew. Chem. Int. Ed., 2015, 54, 828.

5 Representative examples: (a) H. Kuniyasu, A. Ogawa, K.-I. Sato, I. Ryu, N. Kambe, N. Sonoda, J. Am. Chem. Soc., 1992, 114, 5902; (b) A. Ogawa, T. Ikeda, K. Kimura, J. Hirao, J. Am. Chem. Soc., 1999, 121, 5108; (c) S. Burling, L. D. Field, B. A. Messerle, K. Q. Vuong, P. Turner, Dalton Trans., 2003, 4181-4191; (d) C. Cao, L. R. Fraser, J. A. Love, J. Am. Chem. Soc., 2005, 127, 17614; (e) Y. Misumi, H. Seino, Y. Mizobe, J. Organomet. Chem., 2006, 691, 3157; (f) S. Shoai, P. Bichler, B. Kang, H. Buckley, J. A. Love, Organometallics, 2007, 26 , 5778; (g) C. Munro-Leighton, S. A. Delp, N. M. Alsop, E. D. Blue, T. B. Gunnoe, Chem. Commun., 2008, 111; (h) C. J. Weiss, S. D. Wobser, T. J. Marks, J. Am. Chem. Soc., 2009, 131, 2062; (i) V. P. Ananikov, K. A. Gayduck, N. V. Orlov, I. P. Beletskaya, V. N. Khrustalev, M. Y. Antipin, Chem. Eur. J., 2010, 16, 2063; (j) C. J. Weiss, T. J. Marks, J. Am. Chem. Soc., 2010, 132, 10533; (k) R. Gerber, C. M. Frech Chem. Eur. J., 2012, 18, 8901; (I) J. R. Cabrero-Antonino, A. LeyvaPérez, A. Corma, Adv. Synth. Catal., 2012, 354, 678; (m) J.F. Hooper, A. B. Chaplin, C. González-Rodríguez, A. L. Thompson, A. S. Weller, M. C. Willis, J. Am. Chem. Soc., 2012, 134, 2906; (n) S. Kankala, S. Nerella, R. Vadde, C. S. Vasam, RSC Adv., 2013, 3, 23582; (o) Y. Yang, R. M. Rioux, Green Chem., 2014, 16, 3916; (p) A. Cadu, R. A. Watile, S. Biswas, A. Orthaber, P. J. R. Sjöber, J. S. M. Samec, Org. Lett., 2014, 16, 5556; (q) A. B. Pritzius, B. Breit, Angew. Chem. Int. Ed., 2015, 54, 3121; (r) E. S. Degtyareva, J. V. Burykina, A. N. Fakhrutdinov, E. G. Gordeev, V. N. Khrustalev, V. P. Ananikov, ACS Catal., 2015, 5, 7208; (s) G. Kleinhans, G. Guisado-Barrios, D. C. Liles, G. Bertrand, D. I. Bezuidenhout, Chem. Commun., 2016, 52, 3504

6 E. Schaumann, Top. Curr. Chem., 2007, 274, 1.

7 D. J. Berrisford, C. Bolm, K. B. Sharpless, K. B. Angew. Chem., Int. Ed. Engl., 1995, 34, 1059.

8 (a) C. C. Romão, F. E. Kühn, W. A. Herrmann, Chem. Rev., 1997, 97, 3197; (b) T. Nishimura, T. Onoue, K. Ohe, S. Uemura, J. Org. Chem., 1999, 64, 6750; (c) E. M. Ferreira, B. M. Stoltz, J. Am. Chem. Soc., 2003, 125, 9578.

9 (a) A. W. van der Made, R. J. M. Nolte, J. Mol. Cat., 1984, 26, 333; (b) J. Rudolph, K. L. Reddy, J. P. Chiang, K. B. Sharpless, J. Am. Chem. Soc., 1997, 119, 6189.

10 (a) A. N. Campbell, E. B. Meyer, S. S. Stahl, Chem. Commun., 2011, 47, 10257; (b) S. R. Kandukuri, J. A. Schiffner, M. Oestreich, Angew. Chem. Int. Ed., 2012, 51, 1265; (c) X. Wu, Y. Zhao, H. Ge, Chem. Sci., 2015, 6, 5978.

11 A. Nakamura, T. M. J. Anselment, J. Claverie, B. Goodall, R. F. Jordan, S. Mecking, B. Rieger, A. Sen, P. W. N. M. van Leeuwen, K. Nokazi, Acc. Chem. Res., 2013, 46, 1438.

12 (a) E. M. Vogl, H. Gröger, M. Shibasaki, Angew. Chem. Int. Ed., 1999, 38, 1570; (b) I Kamiya, E. Nishinaka, A. Ogawa, J. Org. Chem., 2005, 70, 696; (c) A. J. Pardey, C. Longo, Coord. Chem. Rev., 2010, 254, 254.

13 M. S. Sanford, J. A. Love, R. H. Grubbs, Organometallics, 2001, 20, 5314.

14 C. J. O'Brien, E. A. B. Kantchev, C. Valente, N. Hadei, G. A. Chass, A. Lough, A. C. Hopkinson, M. G. Organ, Chem. Eur. J. 2006, 12, 4743.

15 (a) W. A. Herrmann, Angew. Chem. Int. Ed., 2002, 41, 1290; (b) A. J. Arduengo III, L. I. Iconaru, Dalton Trans., 2009, 6903; (c) S. Díez-González, N. Marion, S. P. Nolan, Chem. Rev., 2009, 109, 3612; (d) M. N. Hopkinson, C. Richter, M.
Schedler F. Glorius, Nature, 2014, 510, 485; (e) J. A. Mata, F. E. Hahn, E. Peris, Chem. Sci., 2014, 5, 1723.

16 (a) A. Di Giuseppe, R. Castarlenas, J. J. Pérez-Torrente, M Crucianelli, V. Polo, R. Sancho, F. J. Lahoz, L. A. Oro, J. Am. Chem. Soc., 2012, 134, 8171; (b) L. Palacios, M. J. Artigas, V. Polo, F. J. Lahoz, R. Castarlenas, J. J. Pérez-Torrente, L. A. Oro, ACS Catal., 2013, 3, 2910.

17 (a) R. Ugo, G. La Monica, S. Cenini, F. Bonati, J. Organomet. Chem., 1968, 11, 159; (b) P. Lahuerta, M. Sanau, L. A. Oro, D. Carmona, Synth. React. Inorg. Met. Org. Chem., 1986 16, 301; (c) C. Gemel, R. John, C. Slugovc, K. Mereiter, R. Schmid, K. Kirchner, J. Chem. Soc., Dalton Trans., 2000 2607; (d) J. M. J. Van Rensburg, A. Roodt, A. Muller, R. Meijboo, Acta Cryst., 2005, E61, m1751.

18 (a) R. Ballardini, G. Varani, M. T. Indelli, F. Scandola, Inorg. Chem., 1986, 25, 3858; (b) A. M. Maroń, J. G. Małecki, M. A. Szala, J. E. Nycz, J. Lumin., 2016, 169, 765-772.

19 (a) Y. Song, H. Xu, W. Chen, P. Zhan, X. Liu, Med. Chem. Commun., 2015, 6, 61; (b) M. Kubanik, H. Holtkamp, T. Söhnel, S. M. F. Jamieson, C. G. Hartinger, Organometallics, 2015, 34, 5658 .

20 (a) H. Janecko, A. M. Trzeciak, J. Ziółkowski, J. Mol. Catal., 1984, 26, 355; (b) V. S. Shestakova, G. K. Shestakov, L. P. Yur'eva, A. A. Belyim O. N. Temkin, Russ. Bull. Chem., 1985, 34, 485; (c) M. Kondo, T. Kochi, F. Kakiuchi, J. Am. Chem. Soc., 2011, 133, 32; (d) A. Di Giuseppe, R. Castarlenas, J. J. Pérez-Torrente, F. J. Lahoz, V. Polo, L. A. Oro Angew. Chem. Int. Ed., 2011, 50, 3938; (e) K. Sakai, T. Kochi, F. Kakiuchi, Org. Lett., 2013, 15, 1024; (f) A. Di Giuseppe, R. Castarlenas, J. J. Pérez-Torrente, F. J. Lahoz, L. A. Oro, Chem. Eur. J., 2014, 20, 8391.

21 L. Palacios, A. Di Giuseppe, A. Opalinska, R. Castarlenas, J. J. Pérez-Torrente, F. J. Lahoz, L. A. Oro Organometallics 2013 32, 2768 and references therein.

22 L. Rubio-Pérez, R. Azpíroz, A. Di Giuseppe, V. Polo, R Castarlenas, J. J. Pérez-Torrente, L. A. Oro, Chem. Eur. J., 2013, 19, 15304

23 (a) O. V. Zenkina, E. C. Keske, G. S. Kochhar, R. Wang, C. M. Crudden, Dalton Trans., 2013, 42, 2282; (b) J. Turek, I. Panov, M. Horáček, Z. Černošek, Z. Padělková, A. Růžiča, Organometallics, 2013, 32, 7234; (c) A. B. Chaplin, Organometallics, 2014, 33, 3069; (d) L. Palacios, A. Di Giuseppe, R. Castarlenas, F. J. Lahoz, J. J. Pérez-Torrente, L. A. Oro Dalton Trans., 2015, 44, 5777.

24 (a) R. Azpíroz, A. L. Rubio-Pérez, A. Di Giuseppe, V. Passarelli, F. J. Lahoz, R. Castarlenas, J. J. Pérez-Torrente, L. A. Oro, ACS Catal., 2014, 4, 4244; (b) E. C. Keske, B. D. Moore, O. V. Zenkina, R. Wang, G. Schatte, C. M. Crudden, Chem. Commun., 2014, 50, 9883; (c) S. Fuertes, A. J. Chueca, V. Sicilia, Inorg. Chem., 2015, 54, 9885.

25 Two septets at $\delta 4.14$ and $2.05 \mathrm{ppm}$ corresponding to the four $\mathrm{CH}$ proton of the isopropyl substituents of the IPr ligand was observed for 7 whereas only one at $3.69 \mathrm{ppm}$ for $\mathbf{5 b}$. A plane of symmetry is present in both complexes.

26 Two doublets at $\delta 2.75$ and $2.10 \mathrm{ppm}\left(J_{\mathrm{H}-\mathrm{H}}=10.4 \mathrm{~Hz}\right)$ were observed for the ethylene ligand of $\mathbf{8}$ whereas only one broad signal at $2.31 \mathrm{ppm}$ for 6 .

27 Y. Dang, S. Qu, Y. Tao, X. deng, Z.-X. Wang, J. Am. Chem. Soc., 2015, 137, 6279.

28 (a) A. M. Mueting; P. Boyle, L. H. Pignolet, Inorg. Chem., 1984, 23, 44; (b) L. Zámostná, T. Braun, B. Braun, Angew. Chem. Int. Ed., 2014, 53, 2745.

29 T. Rappert, O. Nürnberg, N. Mahr, J. Wolf, H. Werner, Organometallics, 1992, 11, 4156.

30 A. M. Geer, J. A. López, M. A. Ciriano, C. Tejel, Organometallics, 2016, 35, 799, and references therein.

31 A. Ohtaka, H. Kuniyasu, M. Kinomoto, H. Kurosawa, J. Am. Chem. Soc., 2002, 124, 14324. 
32 (a) T. Ikada, Y. Mizobe, M. Hidai, Organometallics, 2001, 20, 4441; (b) H. Kuniyasu, F. Yamashita, J. Terao, N. Kambe, Angew. Chem. Int. Ed., 2007, 46, 5929.

33 K. Thomas, J. A. Osborn, A. R. Powell, G. Wilkinson, J. Chem Soc. $A, 1968,1801$

34 (a) C.H. Leung, C. D. Incarvito, R. H. Crabtree, Organometallics, 2006, 25, 6099; (b) J.-N- Luy, S. A. Hauser, A. B. Chaplin, R. Tonner, Organometallics, 2015, 34, 5099.

35 C. A. Urbina-Blanco, S. Manzini, J. Pérez Gomes, A. Doppiu, S. P. Nolan, Chem. Commun., 2011, 47, 5022.

36 (a) C. Bianchini, A. Meli, M. Peruzzini, F. Vizza, P. Frediani, Organometallics, 1990, 9, 1146; (b) J. Navarro, E. Sola, M. Martin, I. T. Dobrinovitch, F. J. Lahoz, L. A. Oro, Organometallics, 2004, 23, 1908; (d) D. Cuervo, J. Díez, M. P. Gamasa, J. Gimeno, Organometallics, 2005, 24, 2224; (e) G. L. O. Wilson, M. Abraha, J. A. Krause, H. Guan, Dalton Trans., 2015, 44, 12128.

37 X. H. Zhang, K. T. Wang, RSC Adv., 2015, 5, 34439.

38 SAINT+, 6.01, Bruker AXS, Inc., Madison, WI, USA, 2000.

39 G. M. Sheldrick, SADABS program, University of Göttingen, Göttingen, Germany, 1999.

40 G. M. Sheldrick, Acta Crystallogr. Sect. A, 1990, 46, 467.

41 G. M. Sheldrick, Acta Crystallogr. Sect. A, 2008, 64, 112.

42 M. J. Frisch, G. W. Trucks, H. B. Schlegel, G. E. Scuseria, M. A. Robb, J. R. Cheeseman, G. Scalmani, V. Barone, B. Mennucci, G. A. Petersson, H. Nakatsuji, M. Caricato, X. Li, H. P. Hratchian, A. F. Izmaylov, J. Bloino, G. Zheng, J. L. Sonnenberg, M. Hada, M. Ehara, K. Toyota, R. Fukuda, J. Hasegawa, M. Ishida, T. Nakajima, Y. Honda, O. Kitao, H. Nakai, T. Vreven, J. A. Montgomery, Jr., J. E. Peralta, F. Ogliaro, M. Bearpark, J. J. Heyd, E. Brothers, K. N. Kudin, V. N. Staroverov, R. Kobayashi, J. Normand, K. Raghavachari, A. Rendell, J. C. Burant, S. S. Iyengar, J. Tomasi, M. Cossi, N. Rega, J. M. Millam, M. Klene, J. E. Knox, J. B. Cross, V. Bakken, C. Adamo, J. Jaramillo, R. Gomperts, R. E. Stratmann, O. Yazyev, A. J. Austin, R. Cammi, C. Pomelli, J. W. Ochterski, R. L. Martin, K. Morokuma, V. G. Zakrzewski, G. A. Voth, P. Salvador, J. J. Dannenberg, S. Dapprich, A. D. Daniels, Ö. Farkas, J. B. Foresman, J. V. Ortiz, J. Cioslowski, and D. J. Fox, Gaussian 09, Revision D.01; Gaussian, Inc., Wallingford CT, 2009.

43 (a) C. Lee, W. Yang, R. G. Parr, Phys. Rev. B: Condens. Matter Mater. Phys., 1988, 37, 785; (b) A. D. J. Becke, Chem. Phys., 1993, 98, 1372; (c) A. D. J. Becke, Chem. Phys., 1993, 98, 5648 .

44 S. Grimme, J. Antony, S. Ehrlich, H. Krieg, J. Chem. Phys., 2010, 132, 154104

45 F. Weigend, R. Ahlrichs, Phys. Chem. Chem. Phys., 2005, 7, 3297. 


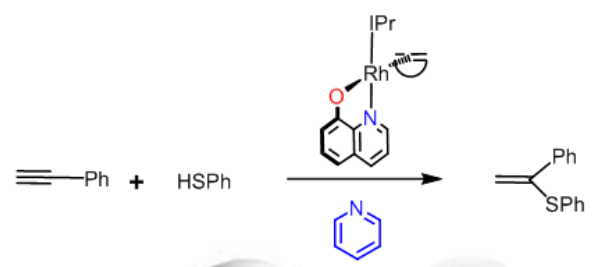

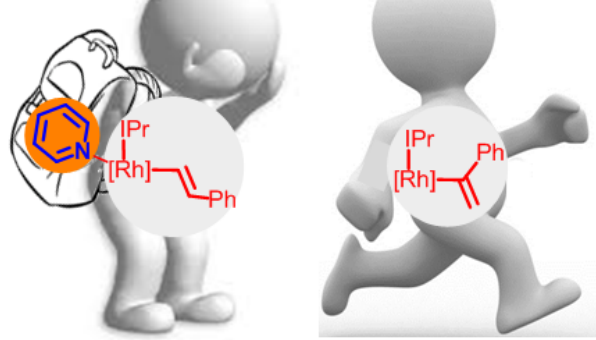

